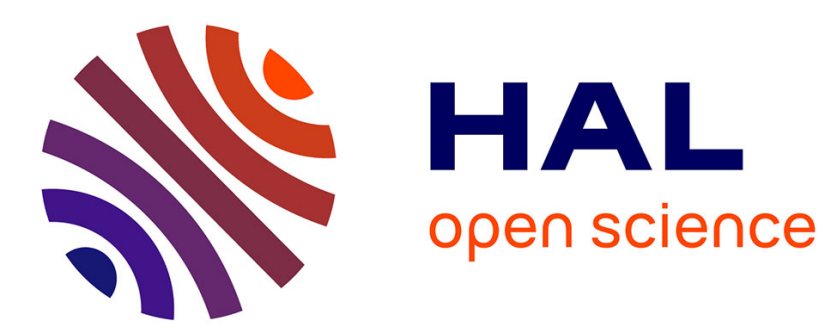

\title{
Modelling of the atmospheric dispersion of mercury emitted from the power sector in Poland
}

\author{
J. Zysk, Y. Roustan, A. Wyrwa
}

\section{To cite this version:}

J. Zysk, Y. Roustan, A. Wyrwa. Modelling of the atmospheric dispersion of mercury emitted from the power sector in Poland. Atmospheric environment, 2015, 112, pp.246-256. 10.1016/j.atmosenv.2015.04.040 . hal-01238312

HAL Id: hal-01238312

https://hal-enpc.archives-ouvertes.fr/hal-01238312

Submitted on 8 Feb 2018

HAL is a multi-disciplinary open access archive for the deposit and dissemination of scientific research documents, whether they are published or not. The documents may come from teaching and research institutions in France or abroad, or from public or private research centers.
L'archive ouverte pluridisciplinaire HAL, est destinée au dépôt et à la diffusion de documents scientifiques de niveau recherche, publiés ou non, émanant des établissements d'enseignement et de recherche français ou étrangers, des laboratoires publics ou privés. 


\title{
Modelling of the atmospheric dispersion of mercury emitted from the power sector in Poland
}

\author{
J. Zyśk ${ }^{\text {a, *, Y. Roustan }}{ }^{\mathrm{b}}$, A. Wyrwa ${ }^{\mathrm{a}}$ \\ a AGH University of Science and Technology, Faculty of Energy and Fuels, Poland \\ ${ }^{\mathrm{b}}$ CEREA Joint Laboratory Ecole des Ponts ParisTech - EDF R\&D, Université Paris-Est, France
}

\section{H I G H L I G H T S}

- Applicability of the new chemical model of mercury was demonstrated.

- Hg reactions with bromine compounds have significant impact on modelling results.

- The contribution of polish sources in monthly $\mathrm{Hg}$ deposition varies from 10 to $22 \%$.

- In some areas power sector is responsible for more than $50 \%$ of total wet deposition.

\section{A R T I C L E I N F O}

\section{Article history:}

Received 14 November 2014

Received in revised form

13 April 2015

Accepted 16 April 2015

Available online 25 April 2015

\section{Keywords:}

Mercury

Modelling

Wet deposition

Chemistry models

Power sector

\begin{abstract}
A B S T R A C T
Poland belongs to the group of EU countries with the highest levels of mercury emissions, with a large portion of these emissions being related to coal combustion. This paper presents a modelling analysis of the impact that the Polish power sector has on the atmospheric concentrations of mercury. A detailed mercury emission inventory is used to analyse the concentration and deposition of mercury. For this study, a chemical scheme devoted to mercury transformations in the atmosphere was implemented into the Polyphemus air quality system. The system was then used to perform simulations for 2008 in two domains i.e. over Europe and over Poland. The impact of various parameters on concentration and wet scavenging of mercury has been analysed. The results of the mercury ambient concentrations and depositions, are presented. Additionally, the contribution of natural and anthropogenic sources to mercury deposition in Poland is shown. The performed works showed that the national sources have low impact to overall deposition, however local contribution in wet deposition of big emitters may reach $50 \%$. Sensitive analysis showed a significant impact of reaction with bromine compound and scavenging coefficient on modelled results of mercury concentration and deposition.
\end{abstract}

(c) 2015 Elsevier Ltd. All rights reserved.

\section{Introduction}

The pathway of mercury dispersion in the atmosphere is complex (Subir et al., 2011). Elemental gaseous mercury - GEM $\left(\mathrm{Hg}^{0}\right)$, can be considered as a global pollutant due to its long lifetime in the atmosphere ( 1 year). Reactive gaseous -RGM $\left(\mathrm{Hg}^{\mathrm{II}}\right.$ and $\left.\mathrm{Hg}^{\mathrm{I}}\right)$ and particulate forms of mercury $\left(\mathrm{Hg}_{\mathrm{P}}\right)$ are deposited more quickly by wet and dry deposition processes. It should be noticed, that after mercury moves through the water chain it can be transformed by aquatic microorganisms into methyl-mercury ( $\mathrm{MeHg}$ ), which is much more toxic than the other forms. Subsequently, $\mathrm{MeHg}$ is

\footnotetext{
* Corresponding author.

E-mail address: jazysk@agh.edu.pl (J. Zyśk).
}

bioaccumulated in living organisms e.g. fish and enters the human food chain (Munthe et al., 2007). This could lead to neurotoxic impacts on people. Evidence of the negative effects of mercury on human health and the environment has led to intergovernmental preparation of a global legally binding instrument on mercury, completed successfully in 2014 (UNEP, 2014)

The monitoring of mercury concentration and deposition over Europe is currently insufficient to provide accurate data on mercury concentrations and depositions. In some parts of Europe there is a lack of sampling stations and thus such areas are not covered by monitoring at all. Therefore, it appears necessary to complement the results of measurements by the modelling methods, keeping in mind the remaining uncertainties of mercury (Subir et al., 2011). One of the key issues in reactive dispersion modelling of mercury is the chemistry model that represents the reactions and mass 
exchange between the gaseous, aqueous and particulate phases. During the last few decades several chemical schemes have been implemented in different Chemistry Transport Models (CTM) developed to represent the atmospheric dispersion of mercury. Some intercomparison works were performed over Europe (Ryaboshapko et al., 2007a), (Ryaboshapko et al., 2007b). These works were taken into account in the implementation of a chemistry scheme devoted to mercury into the framework of the Polyphemus air quality modelling system (Mallet et al., 2007). Some additional refinements have been proposed recently to improve the modelling of mercury fate and transport in the atmosphere, which were incorporated into the analysis. The system was then used to perform simulations for 2008 in two domains i.e. over Europe and Poland with nesting approach to generate the boundary concentration. In Section 2, the mercury dispersion model used for this study is outlined. In Section 3, the configuration of simulations performed for 2008 is described. The results are analysed in Section 4. In that section the impact of the total emissions from Poland, as well as the emissions from the Polish power sector on deposition in Poland is assessed.

\section{Modelling of atmospheric mercury}

\subsection{Implemented chemical scheme}

Many numerical mercury models of Eulerian (ADOM, CAMx, CMAQ-Hg, CMAQ ver. 4.7.1, CTM-Hg, MSCE-HM, MSCE-HM-Hem, GEOS-Chem, ECHMERIT, MOZART, DEHM, GLEMOS, ADOM) and Lagrangian (HYSPLIT, RCTM-Hg) types have been developed to evaluate the atmospheric dispersion of mercury on regional, continental and global scales (Ryaboshapko et al., 2007a). These models consider the main chemical reactions and transformation of mercury in the gaseous and aqueous phases. However, some significant differences can be found, not only in the value of the kinetic rates of the chemical transformations, but also in chemical reactions taken into account. The review of chemicals schemes of mercury implemented in various models, showed some differences compared to our model. For instance oxidation reaction of elemental gaseous mercury with hypobromite radical is only included in GLEMOS, CTM-Hg models (Jonson et al., 2010), (Seigneur et al., 2009). The chemical scheme used for our study takes into account the reactions and transitions of mercury in the gaseous, aqueous and particulate phases presented in Fig. 1. This scheme is an upgraded version of the chemical model previously introduced in (Roustan et al., 2005). The main developments in this model are related to the reactions and transformations of mercury with bromine.

In this model the particulate mercury is distributed among 10 different size sections (between 0.01 and $10 \mu \mathrm{m}$ with the following threshold limits: $0.01-0.02-0.0398-0.0794-0.1585-0.3162-$ $0.6310-1.2589-2.5119-5.0119-10)$. All the equilibrium constants and chemical rates used to quantify the physicochemical processes considered in the chemical scheme are presented in Table 1. The values of parameters were determined based on literature review (relevant references are provided in the last column of Table 1).

Due to the lack of values of Henry constants for $\mathrm{HgBrOH}$ and $\mathrm{HgBr}$ the same values as for $\mathrm{HgBr}_{2}$ were assumed. As presented in Fig. 1 the following compounds: $\mathrm{HgBrOH}$ and $\mathrm{HgBr}_{2}$ are directly derived from $\mathrm{HgBr}$. Therefore, with this assumption the total amount of mercury transformed from the gaseous to the aqueous phase will be equal irrespectively of whether the three compounds of mercury with bromine $\left(\mathrm{HgBr}_{2}, \mathrm{HgBrOH}\right.$ and $\left.\mathrm{HgBr}\right)$ or only one compound i.e. $\mathrm{HgBr}_{2}$ are considered. The mechanism proposed by (Bullock and Brehme, 2002) was adopted to model the sorption and desorption of dissolved $\left[\mathrm{Hg}^{2+}\right]$ on the particulate matter (black

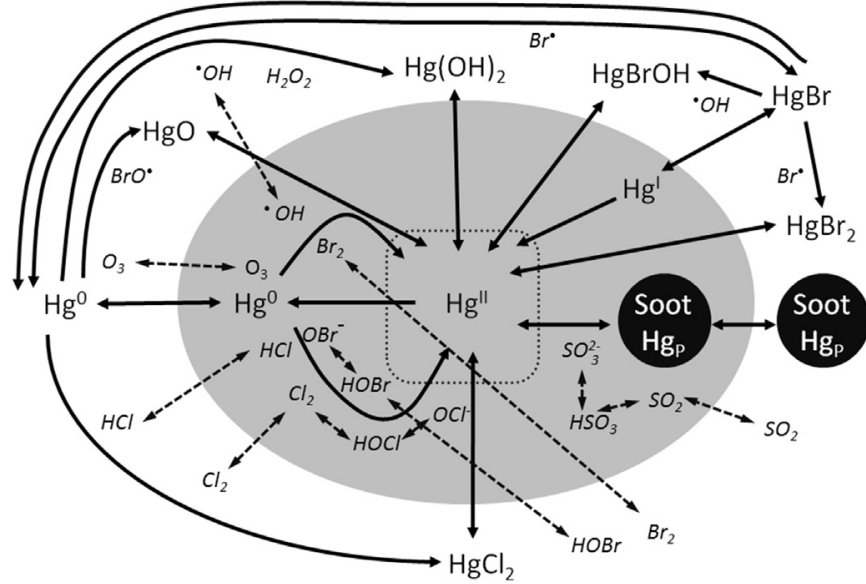

Fig. 1. The implemented chemical model for mercury. In this picture the gaseous and aqueous phases are marked by white and grey, respectively. The line arrows show possible transformations of mercury. The dashed arrows show additional species used in the model which react with mercury.

carbon is the primary sorbent) in the aqueous phase. The sorption coefficient of 680 [ $\mathrm{dm}_{\text {water. }}^{3} \mathrm{gPBC}_{\mathrm{PBC}}^{-3}$ and time constant for the sorption equilibrium of $3600 \mathrm{~s}$ was adopted from work of (Seigneur et al., 1998) and (Bullock and Brehme, 2002), respectively.

The concentration of $\mathrm{SO}_{2}, \mathrm{H}_{2} \mathrm{O}_{2}, \mathrm{O}_{3}, \mathrm{HO}_{2}, \mathrm{OH}^{-}$and black carbon (soot) in aerosols were generated in each cell with a time step $3 \mathrm{~h}$ by simulation run for 2008 with the use of the Polyphemus/Polair air quality model. The evaluation of Polyphemus concentration results over Europe for pollutants such as $\mathrm{PM}, \mathrm{SO}_{2}$ and $\mathrm{O}_{3}$ were presented in the work of (Mallet et al., 2007), (Lecœur and Seigneur, 2013).

The concentrations of other compounds which react with mercury were assumed to be as presented in Table 2 .

It should be noticed that the concentration of those species have a significant influence on mercury reactions in the atmosphere. On the other hand, the mercury concentration does not have a big impact on the concentration of those species. One should bear in mind that the concentration of those species can vary significantly (in particular over Poland due to large big emissions of pollutants) and the chosen values represent only estimates. That it is certainly a simplification and the impact of these assumptions should be examined in future work.

\subsection{Deposition}

For both: gaseous and particulate compounds the dry deposition is represented using the parametric model of vertical eddy fluxes in the atmosphere from (Louis, 1979) for the part of the mass transfer dominated by turbulence. The dry deposition parameterization is completed for gaseous species based on the model presented in (Zhang et al., 2003) with parameters for mercury included in (Zhang et al., 2009). The dry deposition velocities for particulate species were generated based on (Zhang et al., 2001). The use of different sized sections to represent the population of particles leads to different dry deposition velocities for each size section.

The wet deposition is split between in-cloud (rainout) and below cloud (washout) scavenging. The in-cloud scavenging was calculated for elemental mercury $\left(\mathrm{Hg}^{0}\right.$ aq $)$, reactive mercury $\left(\mathrm{Hg}^{\mathrm{II}}{ }_{\mathrm{aq}}\right)$ and particulate $\left(\mathrm{Hg}_{\mathrm{P}}\right)$ species following the parameterization of (Maryon et al., 1996). The cloud presence diagnosis is simply based on a threshold $\left(0.05 \mathrm{~g} . \mathrm{m}^{-3}\right)$ of the liquid water content. The belowcloud scavenging for gaseous mercury compounds $\left(\mathrm{Hg}^{0}, \mathrm{HgO}\right.$, 
Table 1

Physicochemical processes considered in the mercury chemistry model.

\begin{tabular}{|c|c|c|c|}
\hline Reaction & Rate parameter/constant & Units & Reference \\
\hline \multicolumn{4}{|l|}{ Gas-phase oxidation } \\
\hline $\mathrm{Hg}^{0}+\mathrm{O}_{3} \rightarrow \mathrm{HgO}+\mathrm{O}_{2}$ & $2.1 \cdot 10^{-18} \cdot \exp (-1246 / \mathrm{T})$ & $\mathrm{cm}^{3} \cdot \mathrm{molec}^{-1} \cdot \mathrm{s}^{-1}$ & (Hall, 1995) \\
\hline $\mathrm{Hg}^{0}+2 \mathrm{OH} \rightarrow \mathrm{Hg}(\mathrm{OH})_{2}$ & $8.7 \cdot 10^{-14}$ & $\mathrm{~cm}^{3} \cdot \mathrm{molec}^{-1} \cdot \mathrm{s}^{-1}$ & (Sommar et al., 2001) \\
\hline $\mathrm{Hg}^{0}+\mathrm{Cl}_{2} \rightarrow \mathrm{HgCl}_{2}$ & $2.6 \cdot 10^{-18}$ & $\mathrm{~cm}^{3} \cdot \mathrm{molec}^{-1} \cdot \mathrm{s}^{-1}$ & (Ariya et al., 2002) \\
\hline $\mathrm{Hg}^{0}+2 \mathrm{HCl} \rightarrow \mathrm{HgCl}_{2}+\mathrm{H}_{2}$ & $10^{-19}$ & $\mathrm{~cm}^{3} \cdot \mathrm{molec}^{-1} \cdot \mathrm{s}^{-1}$ & (Hall and Bloom, 1993) \\
\hline $\mathrm{Hg}^{0}+\mathrm{H}_{2} \mathrm{O}_{2} \rightarrow \mathrm{Hg}(\mathrm{OH})_{2}$ & $8.4 \cdot 10^{-6} \cdot \exp (-9021 / \mathrm{T})$ & $\mathrm{cm}^{3} \cdot \mathrm{molec}^{-1} \cdot \mathrm{s}^{-1}$ & (Travnikov and Ryaboshapko, 2002) \\
\hline $\mathrm{Hg}^{0}+\mathrm{BrO}^{\bullet} \rightarrow \mathrm{HgO}+\mathrm{Br}$ & $1.5 \cdot 10^{-14}$ & $\mathrm{~cm}^{3} \cdot \mathrm{molec}^{-1} \cdot \mathrm{s}^{-1}$ & (Raofie and Ariya, 2003) \\
\hline $\mathrm{Hg}^{0}+\mathrm{Br}^{\bullet} \rightarrow \mathrm{HgBr}$ & $1.46 \cdot 10^{-32} \cdot(\mathrm{T} / 298)^{-1.86}$ & $\mathrm{~cm}^{6} \cdot \mathrm{molec}^{-2} \cdot \mathrm{s}^{-1}$ & (Donohoue et al., 2006) \\
\hline $\mathrm{HgBr}+\mathrm{Br}^{*} \rightarrow \mathrm{HgBr}_{2}$ & $2.5 \cdot 10^{-10} \cdot \exp (\mathrm{T} / 298)^{-0.57}$ & $\mathrm{~cm}^{3} \cdot \mathrm{molec}^{-1} \cdot \mathrm{s}^{-1}$ & (Goodsite et al., 2004) \\
\hline $\mathrm{HgBr}+{ }^{\bullet} \mathrm{OH} \rightarrow \mathrm{HgBrOH}$ & $2.5 \cdot 10^{-10} \cdot \exp (\mathrm{T} / 298)^{-0.57}$ & $\mathrm{~cm}^{3} \cdot \mathrm{molec}^{-1} \cdot \mathrm{s}^{-1}$ & (Goodsite et al., 2004) \\
\hline \multicolumn{4}{|l|}{ Gas-phase reduction } \\
\hline $\mathrm{HgBr} \rightarrow \mathrm{Hg}^{0}+\mathrm{Br}$ & $1.2 \cdot 10^{10} \cdot \exp (-8357 / \mathrm{T})$ & $\mathrm{s}^{-1}$ & (Goodsite et al., 2004) \\
\hline $\mathrm{HgBr}+\mathrm{Br}^{*} \rightarrow \mathrm{Hg}^{0}+\mathrm{Br}_{2}$ & $3.9 \cdot 10^{-11}$ & $\mathrm{~cm}^{3} \cdot \mathrm{molec}^{-1} \cdot \mathrm{s}^{-1}$ & (Balabanov et al., 2005) \\
\hline \multicolumn{4}{|l|}{ Aqueous-phase oxidation } \\
\hline $\mathrm{Hg}^{0}+\mathrm{O}_{3}+\mathrm{H}^{+} \rightarrow \mathrm{Hg}^{2+}+\mathrm{OH}^{-}+\mathrm{O}_{2}$ & $4.7 \cdot 10^{7}$ & $\mathrm{M}^{-1} \cdot \mathrm{s}^{-1}$ & (Munthe, 1992) \\
\hline $\mathrm{Hg}^{0}+\cdot \mathrm{OH} \rightarrow \mathrm{Hg}^{+}+\mathrm{OH}^{-}$ & $2.0 \cdot 10^{9}$ & $\mathrm{M}^{-1} \cdot \mathrm{s}^{-1}$ & (Lin and Pehkonen, 1997) \\
\hline $\mathrm{Hg}^{0}+\mathrm{HOCl} \rightarrow \mathrm{Hg}^{2+}+\mathrm{OH}^{-}+\mathrm{Cl}^{-}$ & $2.09 \cdot 10^{6}$ & $\mathrm{M}^{-1} \cdot \mathrm{s}^{-1}$ & (Lin and Pehkonen, 1998a) \\
\hline $\mathrm{Hg}^{0}+\mathrm{OCl}^{-}+\mathrm{H}^{+} \rightarrow \mathrm{Hg}^{2+}+\mathrm{OH}^{-}+\mathrm{Cl}^{-}$ & $1.99 \cdot 10^{6}$ & $\mathrm{M}^{-1} \cdot \mathrm{s}^{-1}$ & (Lin and Pehkonen, 1998a) \\
\hline $\mathrm{Hg}^{0}+\mathrm{HOBr} \rightarrow \mathrm{Hg}^{2+}+\mathrm{OH}^{-}+\mathrm{Br}^{-}$ & 0.279 & $\mathrm{M}^{-1} \cdot \mathrm{s}^{-1}$ & (Wang and Pehkonen, 2004) \\
\hline $\mathrm{Hg}^{0}+\mathrm{OBr}^{-}+\mathrm{H}^{+} \rightarrow \mathrm{Hg}^{2+}+\mathrm{Br}^{-}+\mathrm{OH}^{-}$ & 0.273 & $\mathrm{M}^{-1} \cdot \mathrm{s}^{-1}$ & (Wang and Pehkonen, 2004) \\
\hline $\mathrm{Hg}^{0}+\mathrm{Br}_{2} \rightarrow \mathrm{Hg}^{2+}+2 \mathrm{Br}^{-}$ & 0.196 & $\mathrm{M}^{-1} \cdot \mathrm{s}^{-1}$ & (Wang and Pehkonen, 2004) \\
\hline $\mathrm{Hg}^{+}+\left(\cdot \mathrm{OH}, \mathrm{O}_{2}, \mathrm{HO}_{2}^{\cdot}\right) \rightarrow \mathrm{Hg}^{2+}$ & Fast & & (Lin and Pehkonen, 1997) \\
\hline & & & (Pehkonen and Lin, 1998) \\
\hline & & & (Nazhat and Asmus, 1973) \\
\hline \multicolumn{4}{|l|}{ Aqueous-phase reduction } \\
\hline $\mathrm{HgSO}_{3} \rightarrow \mathrm{Hg}^{0}+$ product(SIV) & $7.7 \cdot 10^{13} \mathrm{~T} \cdot \exp (-12595 / \mathrm{T})$ & $\mathrm{s}^{-1}$ & (Van Loon et al., 2000) \\
\hline $\mathrm{Hg}^{2+}+\mathrm{HO}_{2}{ }^{\circ} \rightarrow \mathrm{Hg}^{0}+\mathrm{O}_{2}+\mathrm{H}^{+}$ & $1.1 \cdot 10^{4}$ & $\mathrm{M}^{-1} \cdot \mathrm{s}^{-1}$ & (Pehkonen and Lin, 1998) \\
\hline \multicolumn{4}{|l|}{ Gas/liquid equilibria. } \\
\hline $\mathrm{Hg}_{(\mathrm{g})}^{0} \leftrightarrow \mathrm{Hg}_{(\mathrm{aq})}^{0}$ & 0.11 & M.atm ${ }^{-1}$ & (Sanemasa, 1975) \\
\hline $\mathrm{HgO}_{(\mathrm{g})} \leftrightarrow \mathrm{HgO}_{(\mathrm{aq})}$ & $2.69 \cdot 10^{12}$ & M.atm ${ }^{-1}$ & (Schroeder and Munthe, 1998) \\
\hline $\mathrm{HgCl}_{2(\mathrm{~g})} \leftrightarrow \mathrm{HgCl}_{2(\mathrm{aq})}$ & $1.4 \cdot 10^{6}$ & M.atm ${ }^{-1}$ & (Lindqvist and Rodhe, 1985) \\
\hline $\mathrm{Hg}(\mathrm{OH})_{2(\mathrm{~g})} \leftrightarrow \mathrm{Hg}(\mathrm{OH})_{2(\mathrm{aq})}$ & $1.2 \cdot 10^{4}$ & M.atm ${ }^{-1}$ & (Lindqvist and Rodhe, 1985) \\
\hline $\operatorname{HgBr}_{(\mathrm{g})} \leftrightarrow \mathrm{HgBr}_{(\mathrm{aq})}$ & $1.4 \cdot 10^{6}$ & M.atm ${ }^{-1}$ & this work \\
\hline $\operatorname{HgBr}_{2(\mathrm{~g})} \leftrightarrow \mathrm{HgBr}_{2(\mathrm{aq})}$ & $1.4 \cdot 10^{6}$ & M.atm ${ }^{-1}$ & (Xie et al., 2008) \\
\hline $\mathrm{HgBrOH}_{(\mathrm{g})} \leftrightarrow \mathrm{HgBrOH}_{(\mathrm{aq})}$ & $1.4 \cdot 10^{6}$ & M.atm ${ }^{-1}$ & this work \\
\hline $\mathrm{O}_{3(\mathrm{~g})} \leftrightarrow \mathrm{O}_{3(\mathrm{aq})}$ & $1.13 \cdot 10^{-2}$ & M.atm ${ }^{-1}$ & (Kosak-Channing and Helz, 1983) \\
\hline $\mathrm{SO}_{2(\mathrm{~g})} \leftrightarrow \mathrm{SO}_{2(\mathrm{aq})}$ & 1.23 & M.atm $^{-1}$ & (Smith and Martell, 1976) \\
\hline $\mathrm{Cl}_{2(\mathrm{~g})} \leftrightarrow \mathrm{Cl}_{2(\mathrm{aq})}$ & 0.076 & M.atm ${ }^{-1}$ & (Lin and Pehkonen, 1998b) \\
\hline $\mathrm{OH}_{(\mathrm{g})} \leftrightarrow \mathrm{OH}_{(\mathrm{aq})}$ & 25 & M.atm ${ }^{-1}$ & $(J a c o b, 1986)$ \\
\hline $\mathrm{HO}_{2}{ }^{\bullet}(\mathrm{g}) \leftrightarrow \mathrm{HO}_{2}{ }_{(\mathrm{aq})}$ & $2 \cdot 10^{3}$ & M.atm ${ }^{-1}$ & (Schwartz, 1984) \\
\hline $\mathrm{Br}_{2(\mathrm{~g})} \leftrightarrow \mathrm{Br}_{2(\mathrm{aq})}$ & 0.76 & M.atm ${ }^{-1}$ & (Dean, 1992) \\
\hline $\operatorname{HOBr}_{(\mathrm{g})} \leftrightarrow \operatorname{HOBr}_{(\mathrm{aq})}$ & $6.1 \cdot 10^{3}$ & M.atm ${ }^{-1}$ & (Frenzel et al., 1998) \\
\hline \multicolumn{4}{|l|}{ Aqueous phase equilibria } \\
\hline $\mathrm{Hg}^{2+}+\mathrm{SO}_{3}^{2-} \leftrightarrow \mathrm{HgSO}_{3}$ & $2.1 \cdot 10^{13}$ & $\mathrm{M}^{-1}$ & (Van Loon et al., 2001) \\
\hline $\mathrm{HgSO}_{3}+\mathrm{SO}_{3}^{2-} \leftrightarrow \mathrm{Hg}\left(\mathrm{SO}_{3}\right)_{2}^{2-}$ & $1.0 \cdot 10^{10}$ & $\mathrm{M}^{-1}$ & (Van Loon et al., 2001) \\
\hline $\mathrm{HgCl}_{2} \leftrightarrow \mathrm{Hg}^{2+}+2 \mathrm{Cl}^{-}$ & $10^{-14}$ & $\mathrm{M}^{2}$ & (Sillen and Martell, 1964) \\
\hline $\mathrm{HgOH}^{+} \leftrightarrow \mathrm{Hg}^{2+}+\mathrm{OH}^{-}$ & $2.51 \cdot 10^{-11}$ & M & (Smith and Martell, 1976) \\
\hline $\mathrm{Hg}(\mathrm{OH})_{2} \leftrightarrow \mathrm{Hg}^{2+}+2 \mathrm{OH}^{-}$ & $1.0 \cdot 10^{-22}$ & $\mathrm{M}^{2}$ & (Sillen and Martell, 1964) \\
\hline $\mathrm{HgOHCl} \leftrightarrow \mathrm{HgOH}^{+}+\mathrm{Cl}^{-}$ & $3.72 \cdot 10^{-8}$ & M & (Smith and Martell, 1976) \\
\hline $\mathrm{SO}_{2}+\mathrm{H}_{2} \mathrm{O} \leftrightarrow \mathrm{HSO}_{3}^{-}+\mathrm{H}^{+}$ & $1.23 \cdot 10^{-2}$ & M & (Smith and Martell, 1976) \\
\hline $\mathrm{HSO}_{3}^{-} \leftrightarrow \mathrm{SO}_{3}^{2-}+\mathrm{H}^{+}$ & $6.6 \cdot 10^{-8}$ & M & (Smith and Martell, 1976) \\
\hline $\mathrm{Cl}_{2}+\mathrm{H}_{2} \mathrm{O} \leftrightarrow \mathrm{HOCl}+\mathrm{Cl}^{-}+\mathrm{H}^{+}$ & $5.0 \cdot 10^{-4}$ & $\mathrm{M}^{2}$ & (Lin and Pehkonen, 1998a) \\
\hline $\mathrm{HOCl} \leftrightarrow \mathrm{OCl}^{-}+\mathrm{H}^{+}$ & $3.2 \cdot 10^{-8}$ & M & (Lin and Pehkonen, 1998a) \\
\hline $\mathrm{Hg}^{2+}+\mathrm{Br}^{-} \leftrightarrow \mathrm{HgBr}^{+}$ & $1.1 \cdot 10^{9}$ & $\mathrm{M}^{-1}$ & (Hepler and Olofsson, 1975) \\
\hline $\mathrm{HgBr}^{+}+\mathrm{Br}^{-} \leftrightarrow \mathrm{HgBr}_{2}$ & $2.5 \cdot 10^{8}$ & $\mathrm{M}^{-1}$ & (Hepler and Olofsson, 1975) \\
\hline $\mathrm{HgBr}_{2}+\mathrm{Br}^{-} \leftrightarrow \mathrm{HgBr}_{3}^{-}$ & $1.5 \cdot 10^{2}$ & $\mathrm{M}^{-1}$ & (Hepler and Olofsson, 1975) \\
\hline $\mathrm{HgBr}_{3}^{-}+\mathrm{Br}^{-} \leftrightarrow \mathrm{HgBr}_{4}^{2-}$ & $2.3 \cdot 10^{1}$ & $\mathrm{M}^{-1}$ & (Hepler and Olofsson, 1975) \\
\hline $\mathrm{HOBr} \leftrightarrow \mathrm{H}^{+}+\mathrm{BrO}^{-}$ & $2.51 \cdot 10^{-9}$ & $\mathrm{M}^{-1}$ & (Wang and Pehkonen, 2004) \\
\hline $\mathrm{Br}_{2}+\mathrm{H}_{2} \mathrm{O} \leftrightarrow \mathrm{HOBr}+\mathrm{Br}^{-}+\mathrm{H}^{+}$ & $5.75 \cdot 10^{-9}$ & $\mathrm{M}^{-1}$ & (Wang and Pehkonen, 2004) \\
\hline $\mathrm{H}^{+}+\mathrm{Br}^{-}+\mathrm{Hg}(\mathrm{OH})_{2} \leftrightarrow \mathrm{HgBrOH}$ & $2.7 \cdot 10^{-12}$ & $\mathrm{M}^{-2}$ & (Poulain et al., 2007) \\
\hline \multicolumn{4}{|l|}{ Gas/soot equilibria } \\
\hline $\operatorname{soot}_{(\mathrm{g})} \rightarrow \operatorname{soot}_{(\mathrm{aq})}$ & $1 \cdot 10^{5}$ & $\mathrm{~m}_{\text {water }}^{3} \cdot \mathrm{m}_{\mathrm{air}}^{-3}$ & (Petersen et al., 1995) \\
\hline
\end{tabular}

$\mathrm{HgCl}_{2}, \mathrm{Hg}(\mathrm{OH})_{2}, \mathrm{HgBr}, \mathrm{HgBr}_{2}, \mathrm{HgBrOH}$ ) was calculated based on the parameterization proposed by (Sportisse and du Bois, 2002). The below cloud scavenging for particulate mercury is computed with the parameterization proposed by (Seinfeld, 1985). Following (Willis, 1984) the representative diameter for the rain is given as a function of the rain intensity. The raindrop velocity is calculated as the function of the raindrop diameter following (Uplinger, 1981).

\section{Simulation setting}

Simulations were performed for the year 2008 for two domains covering Poland and Europe with the use of the Polair3D CTM included in the Polyphemus platform. The main aims of the simulation over Europe were: (i) to prepare boundary concentration for the finer domain covering Poland and (ii) to evaluate the 
Table 2

Concentration of species which react with mercury.

\begin{tabular}{|c|c|c|c|}
\hline Species & Concentration & Units & References \\
\hline $\mathrm{HCl}$ & Linear interpolation from $1.2 \cdot 10^{10}$ at surface level to $10^{8}$ at $10 \mathrm{~km}$ altitude & molec.cm ${ }^{-3}$ & $\begin{array}{l}\text { (Seigneur et al., 2009) who based } \\
\text { on (Graede and Keene, 1996) }\end{array}$ \\
\hline $\mathrm{Cl}_{2}$ & $\begin{array}{l}100 \text { during night over sea at surface level } \\
50 \text { during night over sea above surface level } \\
10 \text { during day over sea }\end{array}$ & ppt & (Spicer et al., 1998) \\
\hline $\mathrm{BrO}^{\circ}$ & 0.3 & pptv & (Yang et al., 2005) \\
\hline $\mathrm{Br}^{-}$ & 0.003 & pptv & (Seigneur et al., 2009) \\
\hline $\mathrm{Br}_{2}$ & 0.003 & pptv & (Yang et al., 2005) \\
\hline $\mathrm{HOBr}$ & 1 & pptv & (Yang et al., 2005) \\
\hline $\mathrm{Cl}^{-}$ & $7 \cdot 10^{-5}$ & g.mol ${ }^{-1}$ & (Ryaboshapko et al., 2003) \\
\hline
\end{tabular}

received results against the measurements done through the EMEP stations network.

The year 2008 was chosen because most of the input data e.g. meteorological or emissions as well as the mercury measurement data used for the evaluation of the results were available. Moreover, the detailed mercury emission inventory for Poland was available for 2008. The second domain was used to analyse the mercury transport over Poland in a more detailed way.

\subsection{Domain of simulation}

The European domain starting from $14.5^{\circ} \mathrm{W}$ longitude and $35.0^{\circ} \mathrm{N}$ latitude, consists of $120 \times 140$ cells with a horizontal resolution of $0.5^{\circ} \times 0.25^{\circ}$ (along longitude and latitude respectively). The domain over Poland consisted of $118 \times 80$ cells, starting from $13.55^{\circ} \mathrm{E}$ longitude and $47.95^{\circ} \mathrm{N}$ latitude with a horizontal resolution of $0.1^{\circ}$ (Fig. 2). Ten vertical levels were used with the following limits [in meters above surface]: $0 ; 70 ; 150 ; 300 ; 500 ; 750 ; 1000$; 2000; 3000; 5000 .

\subsection{Input data}

\subsubsection{Meteorological data}

The meteorological parameters were taken from (ECMWF) meteorological data for 2008. The ECMWF data are provided with a resolution of $0.25^{\circ}$ on 54 vertical levels every $3 \mathrm{~h}$. The vertical turbulent transport is represented through a diffusion coefficient computed using the Troen and Mahrt (Troen and Mahrt, 1986) parameterization within the boundary layer, and the Louis (Louis, 1979) parameterization above it.

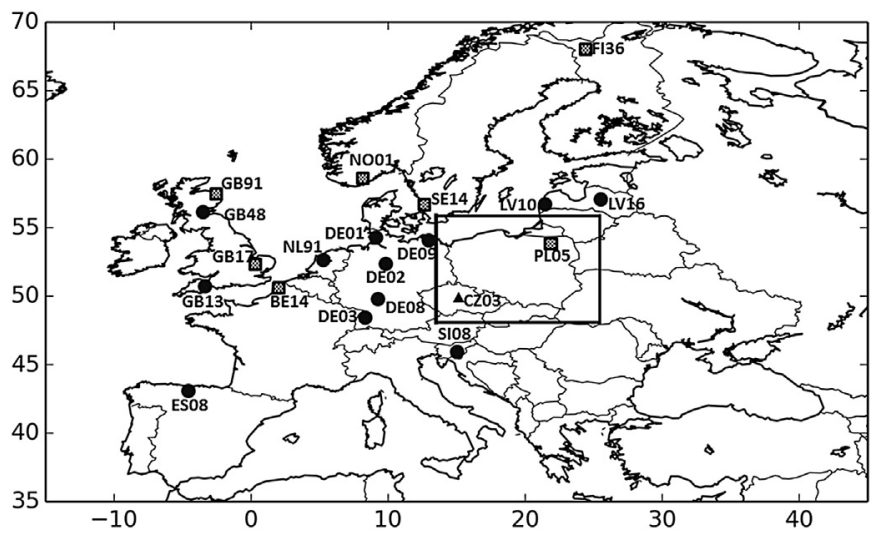

Fig. 2. Domains of simulations and location of measurement stations of mercury wet deposition (circles), ambient concentration (triangles) or both parameters (squares) operated in 2008 in the frame of (EMEP-CCC, 2013).

\subsubsection{Land data}

A database from the United States Geological Survey, the Global Land Cover Characteristics ((GLCC/USGS, 2008), version 2.0, Lambert Azimuthal Equal Area, $1 \mathrm{~km}$ ) were used to describe land use coverage.

\subsubsection{Anthropogenic emissions}

For the first simulation over Europe, data provided by the (CEIP/ EMEP, 2013) program was used. (CEIP/EMEP, 2013) yearly emission fluxes are provided with a horizontal resolution of approximately $50 \times 50 \mathrm{~km}$ base on emission data reported by the membership countries (see Fig. 3). Based on (Pacyna et al., 2006) mercury emissions from (CEIP/EMEP, 2013) inventory were disaggregated into its three main forms: $\mathrm{Hg}^{0}, \mathrm{Hg}^{\text {II }}, \mathrm{Hg}_{\mathrm{P}}$ with the following speciation: $61 \%, 32 \%, 7 \%$, respectively. This emissions were split among the three lowest vertical levels $0-70,71-150$ and $151-300$ [m] with the rate 37\%, 38\%, 25\% receptively based on (Travnikov and Ilyin, 2005).

The emission of mercury in Poland, estimated approximately to $15.7 \mathrm{Mg}$ in 2008 (KOBiZE, 2011) was the highest from all EU countries (CEIP/EMEP, 2013). Most of the emissions are released from the power sector, for instance $8.8 \mathrm{Mg}$ of mercury was emitted into air from power sector in 2008.

For a second simulation run over Poland two databases of emissions from Polish power sector were used (i) our own estimation of emissions $(Z)$ from the power sector and (ii) EMEP data (E). The first database i.e. $Z$ was prepared based on a bottom-up approach presented in (Zyśk et al., 2011). It used the technology database which has been updated for 2008 in relation to installed boilers and emission controls, as well as coal consumption based on national statistics. The emission of mercury was estimated to be equal to $3.1 \mathrm{Mg}$ and $11.7 \mathrm{Mg}$ for hard and brown coal power plants,

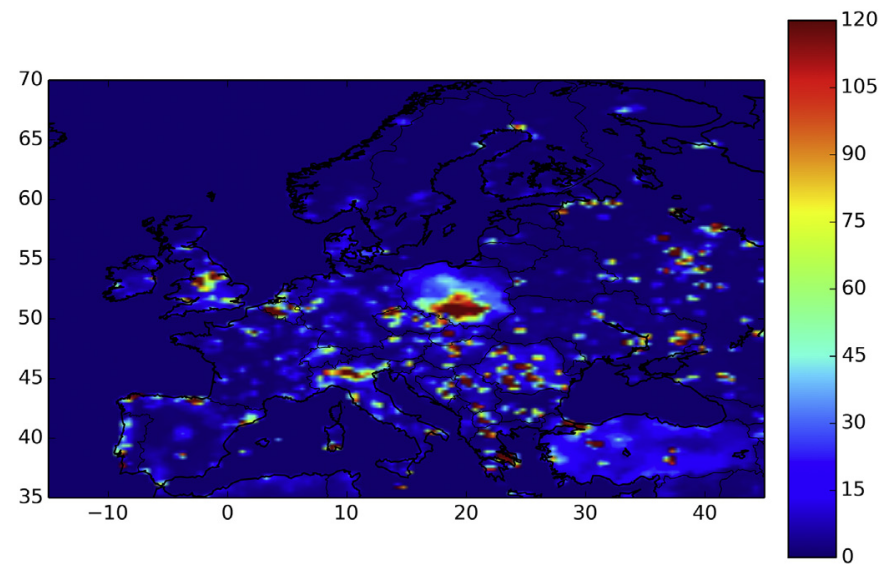

Fig. 3. Anthropogenic emission over Europe in $2008\left[\mathrm{~g} \cdot \mathrm{km}^{-2} \cdot \mathrm{y}^{-1}\right]$ due to (CEIP/EMEP, 2013). 
respectively. Compared to 2005 the emissions decreased $20 \%$ mainly thanks to significant investments in emission control installations. The shares of three forms of mercury on total emissions changed slightly compared to 2005 and in 2008 were equal to $\mathrm{Hg}^{0}$ $-76 \%, \mathrm{Hg}^{\mathrm{II}}-18 \%$ and $\mathrm{Hg}_{\mathrm{p}}-6 \%$.

It was assumed that emissions of reactive gaseous mercury $\mathrm{Hg}^{\mathrm{II}}$ is equally distributed into the following mercury compounds: $\mathrm{HgBr}_{2}, \mathrm{HgO}, \mathrm{HgCl}_{2}, \mathrm{Hg}(\mathrm{OH})_{2}$. Two options for distribution of the aerosol-bound mercury in ten size sections: (i) equal distribution or (ii) in proportion to the surface of aerosols sections. The temporal (monthly, weekly and hourly) emissions profiles were adopted based on: (i) data of emissions from different sectors (CEIP/EMEP, 2013), (KOBiZE, 2011), (ii) time profiles of activity during a year for different sectors in Europe provided by (Friedrich and Reis, 2004).

\subsubsection{Natural emissions}

Data on natural emissions and reemissions provided by (CEIP/ EMEP, 2013) were used. The data are stored as yearly average natural mercury emission fluxes with a resolution of $50 \times 50 \mathrm{~km}$ covering the whole Europe (Fig. 4). The (CEIP/EMEP, 2013) accepted the approach provided by (Travnikov and Ilyin, 2005). It has been assumed that all emissions of mercury from non-anthropogenic sources were in the form of $\mathrm{Hg}^{0}$ and occur at ground level.

\subsubsection{Boundary and initial concentration}

The initial and boundary concentration were set to $0.0012 \mathrm{ppt}$ for $\mathrm{HgO}, \mathrm{Hg}(\mathrm{OH})_{2}, \mathrm{HgCl}_{2}, \mathrm{Hg}_{\mathrm{P}}$ and $0.185 \mathrm{ppt}$ for $\mathrm{Hg}^{0}$. At the first level, the concentration equals to approximately $5 \mathrm{pg} \cdot \mathrm{m}^{-3}$ for $\mathrm{HgO}$, $\mathrm{Hg}(\mathrm{OH})_{2}, \mathrm{HgCl}_{2}, \mathrm{Hg}_{\mathrm{P}}$ and $1.5 \mathrm{ng} \cdot \mathrm{m}^{-3}$ for $\mathrm{Hg}^{0}$. The boundary and initial concentrations of $\mathrm{Hg}_{\mathrm{P}}$ are equally distributed among the 10 size sections. The concentrations of mercury compounds in the aqueous phase and of mercury compounds including bromine were set to 0 . The chosen values were selected on the basis of simulation results and measurements of mercury compounds in the air over Europe (Roustan and Bocquet, 2006), (Jonson et al., 2010).

\section{Results}

A reference version of the model was evaluated by comparison to the available observations of air concentration and wet deposition of mercury. Thereafter the results of a sensitivity study performed to assess the impact of some key modelling choices are discussed. Finally two applications of the model are considered. The first one is an evaluation at European scale of the contribution of different sources to mercury deposition in Poland. The second one,

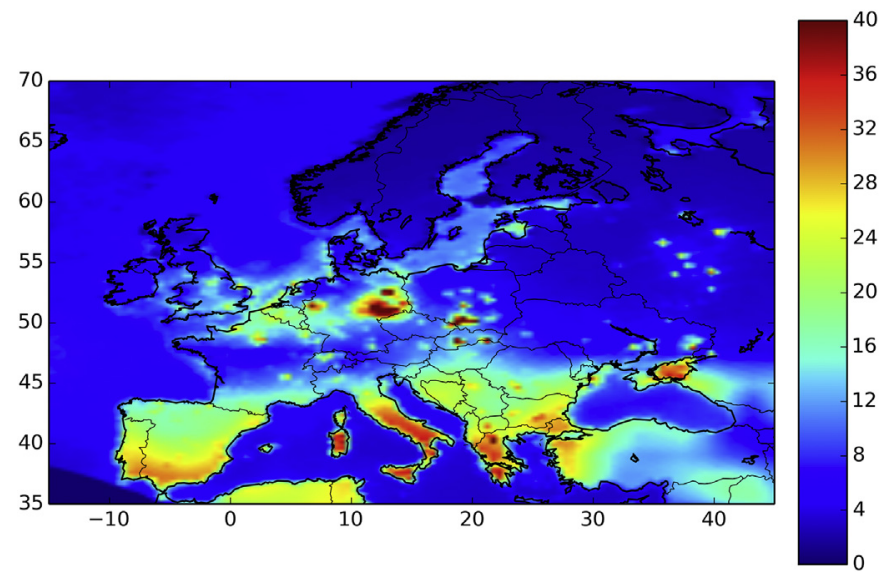

Fig. 4. Natural emission and reemission over Europe $\left[\mathrm{g} \cdot \mathrm{km}^{-2} \cdot \mathrm{y}^{-1}\right]$ due to (CEIP/EMEP, 2013). at Polish scale is focused on an evaluation of the contribution of the power sector.

\subsection{Evaluation}

In Europe continuous mercury measurements are done by the EMEP stations within the framework of the Convention on Longrange Transboundary Air Pollution (EMEP-CCC, 2013). For 2008, the measurements of mercury concentrations and wet depositions are provided by 8 and 19 stations, respectively (Fig. 2). In eight stations the concentration of $\mathrm{Hg}_{\mathrm{P}}$ were also measured. Unfortunately, due to application of different measurement methodology it is difficult to use the obtained observations to evaluate models (Aas and Breivik, 2007). The mercury dispersion models are usually evaluated against measurements of wet deposition (e.g. (Ilyin et al., 2010a)). Indeed, the measured atmospheric concentration of mercury is dominated by a high concentration of elemental gaseous mercury $\left(\mathrm{Hg}^{0}\right)$, which is around 25 times higher than the concentration of its other forms ( $\mathrm{RGM}+\mathrm{Hg}_{\mathrm{p}}$ ). The relatively long lifetime of $\mathrm{Hg}^{0}$ in the atmosphere makes it rather evenly distributed in the global atmosphere. Therefore, the modelled concentration of elemental gaseous mercury does not provide too much information on the scientific correctness of the applied model. Another information can be obtained by provision of concentration/deposition of reactive gaseous mercury (RGM) and mercury bounded in aerosols $\mathrm{Hg}_{\mathrm{P}}$. These forms are dispersed in the atmosphere locally and their deposition pattern strongly depends on local sources. Due to the lack of measurements of the atmospheric concentration of RGM in the EMEP station, the best approach is to compare results of wet deposition. The results of the model comparison against measurements for wet mercury deposition are presented in Table 3. To mitigate the influence of the amount of precipitation, the modelling results were multiplied by the ratio of precipitation measured at (EMEP-CCC, 2013) stations and precipitation from meteorological input data.

The overestimation and underestimation of wet deposition was observed in 13 and 6 stations, respectively (Table 3). The modelled result of wet deposition of mercury were in station GB17 were nearly 2.5 times higher and in station PL05 4 times lower than observation. Large overestimation of the modelled results is observed mainly in winter's months. In most of the stations the strong correlation exists between monthly precipitation rate and wet deposition load (correlation coefficient is above 0.7 in 11 stations). In general, the modelling results obtained were underestimated nearly $5 \%$ compared to measurements of wet deposition and underestimated approx. 20\% compared to measurements of concentration of gaseous mercury in ambient air. The high underestimation of modelled mercury wet deposition was observed in summer. During this period the anthropogenic mercury emissions are the lowest and the reactive mercury comes from atmospheric reactions. The oxidation processes are more intensive than these represented in the model. The most reaction rate constants provided to the model are constant for all temperatures. The difference in the amount of mercury removed by wet scavenging process in the location of the measurement stations PL05 based on the data of two anthropogenic emissions i.e. E and $Z$ can reach 5\% (Table 3). The total emission of mercury from Polish power sector differed by $40 \%$, however, the emission of $\mathrm{Hg}^{\mathrm{II}}$ and $\mathrm{Hg}_{\mathrm{P}}$ in both cases were almost the same (as different speciation factors were used in $\mathrm{E}$ and $\mathrm{Z}$ to split total mercury emissions into three main forms).

\subsection{Sensitivity analysis}

Simulations were run to investing the impact of different model set on the concentration and deposition of mercury in Europe. The 
Table 3

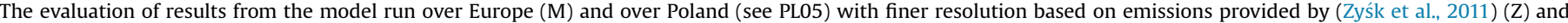

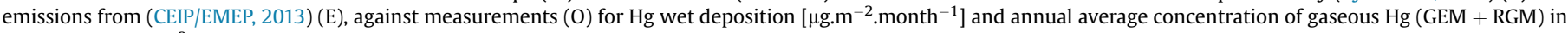
ambient air [ng.m ${ }^{-3}$ ].

\begin{tabular}{|c|c|c|c|c|c|c|c|c|c|c|c|c|c|c|}
\hline \multirow[t]{3}{*}{ Stations } & \multicolumn{13}{|c|}{ Wet deposition } & \multirow{3}{*}{$\frac{\text { Conc }}{\text { Year }}$} \\
\hline & \multicolumn{13}{|c|}{ Months } & \\
\hline & $\mathrm{J}$ & $\mathrm{F}$ & M & A & M & $\mathrm{J}$ & $\mathrm{J}$ & A & $\mathrm{S}$ & 0 & $\mathrm{~N}$ & D & & \\
\hline \multirow[t]{2}{*}{ BE14 } & $\mathrm{O}$ & 0.12 & 0.11 & 2.27 & 0.11 & 0.49 & 0.46 & 0.63 & 1.38 & 0.33 & 0.26 & 0.31 & 0.17 & 1.84 \\
\hline & $\mathrm{M}$ & 0.20 & 0.19 & 0.66 & 0.17 & 0.63 & 0.46 & 0.52 & 0.73 & 0.64 & 0.60 & 0.61 & 0.50 & 1.34 \\
\hline \multirow[t]{2}{*}{ CZ03 } & $\mathrm{O}$ & & & & & & & & & & & & & 1.55 \\
\hline & M & & & & & & & & & & & & & 1.14 \\
\hline \multirow[t]{2}{*}{ DE01 } & $\mathrm{O}$ & 0.47 & 0.22 & 0.29 & 0.18 & 0.15 & 0.30 & 1.02 & 1.11 & 0.43 & 0.46 & 0.34 & 0.40 & \\
\hline & M & 0.69 & 0.74 & 0.69 & 0.30 & 0.15 & 0.35 & 0.48 & 1.58 & 0.68 & 1.10 & 0.85 & 0.61 & \\
\hline \multirow[t]{2}{*}{ DE02 } & $\mathrm{O}$ & 0.31 & 0.41 & 0.54 & 0.61 & 0.20 & 1.03 & 0.89 & 1.22 & 0.31 & 0.34 & 0.21 & 0.10 & \\
\hline & M & 0.95 & 0.44 & 0.52 & 0.57 & 0.24 & 0.59 & 0.93 & 0.96 & 0.24 & 0.77 & 0.71 & 0.61 & \\
\hline \multirow[t]{2}{*}{ DE03 } & $\mathrm{O}$ & 0.42 & 0.70 & 1.08 & 1.66 & 1.19 & 1.37 & 2.00 & 1.70 & 0.84 & 1.14 & 0.40 & 0.35 & \\
\hline & $\mathrm{M}$ & 1.16 & 0.89 & 1.57 & 2.12 & 0.67 & 0.98 & 1.02 & 1.55 & 1.00 & 2.21 & 1.06 & 0.61 & \\
\hline \multirow[t]{2}{*}{ DE08 } & $\mathrm{O}$ & 0.49 & 0.30 & 0.80 & 1.02 & 0.36 & 1.05 & 1.86 & 1.37 & 0.92 & 1.20 & 0.48 & 0.42 & \\
\hline & $\mathrm{M}$ & 1.19 & 1.09 & 1.03 & 1.01 & 0.22 & 0.39 & 1.24 & 1.23 & 0.81 & 1.91 & 1.15 & 0.61 & \\
\hline \multirow[t]{2}{*}{ DE09 } & $\mathrm{O}$ & 0.21 & 0.16 & 0.30 & 0.55 & 0.21 & 0.38 & 0.37 & 0.47 & 0.26 & 0.26 & 0.40 & 0.10 & \\
\hline & $\mathrm{M}$ & 0.35 & 0.38 & 0.44 & 1.19 & 0.36 & 0.18 & 0.48 & 0.49 & 0.45 & 0.54 & 0.79 & 0.33 & \\
\hline \multirow{2}{*}{ ES08 } & $\mathrm{O}$ & 0.30 & 0.13 & 1.27 & 0.62 & 0.51 & 0.99 & 0.28 & 0.77 & 0.23 & & 0.56 & 0.43 & \\
\hline & $\mathrm{M}$ & 0.37 & 0.17 & 1.68 & 1.18 & 1.04 & 1.48 & 0.49 & 0.78 & 0.80 & & 2.40 & 1.74 & \\
\hline \multirow[t]{2}{*}{ FI36 } & $\mathrm{O}$ & 0.02 & 0.06 & 0.09 & 0.10 & 0.06 & 0.76 & 0.82 & 0.32 & 0.11 & 0.06 & & & 1.37 \\
\hline & $\mathrm{M}$ & 0.02 & 0.06 & 0.15 & 0.13 & 0.05 & 0.51 & 0.44 & 0.36 & 0.16 & 0.12 & & & 1.25 \\
\hline \multirow[t]{2}{*}{ GB13 } & 0 & 0.39 & 0.59 & 1.50 & 1.56 & 0.71 & 0.41 & 0.42 & 0.51 & 0.49 & 0.37 & 0.30 & 0.12 & \\
\hline & $\mathrm{M}$ & 0.35 & 0.71 & 0.80 & 0.54 & 1.07 & 0.54 & 1.13 & 1.39 & 0.77 & 0.91 & 0.84 & 0.51 & \\
\hline \multirow[t]{2}{*}{ GB17 } & $\mathrm{O}$ & & 0.08 & 0.39 & 0.46 & & & & & & 0.11 & 0.17 & 0.54 & 1.71 \\
\hline & $\mathrm{M}$ & & 0.13 & 0.30 & 0.47 & & & & & & 0.30 & 0.63 & 2.49 & 1.27 \\
\hline \multirow[t]{2}{*}{ GB48 } & $\mathrm{O}$ & 0.41 & 0.28 & 0.49 & 0.50 & 0.25 & 0.31 & 0.41 & 0.56 & 0.24 & 0.19 & 0.14 & 0.28 & \\
\hline & $\mathrm{M}$ & 0.67 & 0.56 & 0.53 & 0.40 & 0.23 & 0.67 & 1.01 & 1.44 & 0.99 & 0.66 & 0.64 & 0.46 & \\
\hline \multirow[t]{2}{*}{ GB91 } & $\mathrm{O}$ & 0.19 & 0.04 & 0.26 & 0.49 & 0.19 & 0.49 & 0.46 & 0.41 & 0.20 & 0.10 & 0.23 & 0.08 & 0.84 \\
\hline & $\mathrm{M}$ & 0.29 & 0.09 & 0.39 & 0.43 & 0.23 & 0.57 & 0.81 & 0.79 & 0.83 & 0.23 & 1.03 & 0.43 & 1.24 \\
\hline \multirow[t]{2}{*}{ LV10 } & 0 & 1.12 & 0.73 & 1.07 & 1.42 & 0.36 & 2.31 & 1.75 & 3.82 & 1.60 & 5.48 & 3.08 & 1.69 & \\
\hline & $\mathrm{M}$ & 1.06 & 0.75 & 0.49 & 0.50 & 0.24 & 0.74 & 0.79 & 1.51 & 0.87 & 2.00 & 1.40 & 1.10 & \\
\hline \multirow[t]{2}{*}{ LV16 } & $\mathrm{O}$ & 0.51 & 0.81 & 0.87 & 1.89 & 0.46 & 1.67 & 2.53 & 3.31 & 0.43 & 1.46 & 2.41 & 1.67 & \\
\hline & $\mathrm{M}$ & 0.66 & 1.04 & 0.63 & 0.76 & 0.17 & 0.46 & 0.63 & 1.16 & 0.28 & 1.38 & 1.03 & 0.62 & \\
\hline NL91 & $\mathrm{O}$ & 0.39 & 0.24 & 0.93 & 0.25 & 0.78 & 0.55 & 1.52 & 1.80 & 0.80 & 0.66 & 0.72 & 0.29 & \\
\hline & $\mathrm{M}$ & 0.67 & 0.56 & 0.53 & 0.40 & 0.23 & 0.67 & 1.01 & 1.44 & 0.99 & 0.66 & 0.64 & 0.46 & \\
\hline NO01 & $\mathrm{O}$ & 1.24 & 0.76 & 1.49 & 1.28 & 0.25 & 1.44 & 1.10 & 1.09 & 0.83 & 0.82 & 0.52 & 0.15 & 1.73 \\
\hline & $\mathrm{M}$ & 3.73 & 1.29 & 2.16 & 1.82 & 0.20 & 0.62 & 0.69 & 1.29 & 1.61 & 2.18 & 1.65 & 1.96 & 1.20 \\
\hline PL05 & 0 & 5.88 & 2.61 & 2.60 & 3.26 & 2.12 & 1.13 & 0.76 & 2.39 & 1.35 & 2.90 & 2.98 & 1.93 & 1.47 \\
\hline & $\mathrm{M}$ & 0.69 & 0.86 & 0.62 & 0.40 & 0.54 & 0.53 & 0.37 & 1.13 & 0.41 & 0.88 & 0.72 & 0.64 & 1.16 \\
\hline & $\mathrm{Z}$ & 0.69 & 0.90 & 0.69 & 0.40 & 0.57 & 0.56 & 0.41 & 1.31 & 0.41 & 0.93 & 0.73 & 0.61 & 1.17 \\
\hline & $E$ & 0.64 & 0.82 & 0.64 & 0.39 & 0.57 & 0.52 & 0.39 & 1.27 & 0.40 & 0.89 & 0.70 & 0.58 & 1.16 \\
\hline SE14 & $\mathrm{O}$ & 0.64 & 0.23 & 0.49 & 0.20 & 0.42 & 1.09 & 0.80 & 0.51 & 0.66 & 0.49 & 0.52 & 0.16 & 1.57 \\
\hline & $\mathrm{M}$ & 0.96 & 0.32 & 0.64 & 0.18 & 0.18 & 0.56 & 0.62 & 0.83 & 0.66 & 0.89 & 0.95 & 0.33 & 1.23 \\
\hline SI08 & $\mathrm{O}$ & & & & & & 0.90 & 1.25 & 0.16 & 0.15 & 0.27 & 0.26 & 1.54 & \\
\hline & $\mathrm{M}$ & & & & & & 0.52 & 1.23 & 0.89 & 0.58 & 0.79 & 1.10 & 3.12 & \\
\hline
\end{tabular}

results were compared to basic set of model, described in Sections 2 and 3.

The models was run without (i) chemistry in gaseous and aqueous phases, (ii) reaction $\mathrm{Hg}^{\mathrm{O}}+\mathrm{BrO}^{\circ} \rightarrow \mathrm{HgO}+\mathrm{Br}$ and (iii) dry deposition of $\mathrm{Hg}^{\mathrm{O}}$. The model was also run with the emissions of aerosol-bound mercury distributed in the ten size sections in proportion to the surface of aerosols sections instead of equal distribution used in others presented simulations and with boundary concentration higher of $20 \%$ of all mercury forms. The corresponding impact of these sets on the results of ambient concentration, dry and wet deposition load of elemental gaseous, reactive gaseous and aerosol-bound in whole domain is presented in Table 4.

The different scavenging coefficients and representative

Table 4

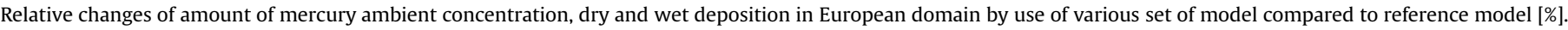

\begin{tabular}{|c|c|c|c|c|c|c|}
\hline Result & Mercury forms & No chemistry & $\begin{array}{l}\text { No reaction } \\
\mathrm{Hg}^{0}+\mathrm{BrO} \rightarrow \mathrm{HgO}+\mathrm{Br}\end{array}$ & No dry deposition of $\mathrm{Hg}^{0}$ & $\begin{array}{l}\text { Boundary concentration } \\
\text { higher of } 20 \%\end{array}$ & $\begin{array}{l}\mathrm{Hg}_{\mathrm{p}} \text { surface } \\
\text { proportion }\end{array}$ \\
\hline \multirow{3}{*}{$\begin{array}{l}\text { Ambient } \\
\text { concentration }\end{array}$} & $\mathrm{Hg}^{0}$ & 1.03 & 1.02 & 1.07 & 1.18 & 1.00 \\
\hline & $\mathrm{Hg}^{\mathrm{II}}$ & 0.44 & 0.67 & 1.02 & 1.16 & 1.00 \\
\hline & $\mathrm{Hg}_{\mathrm{P}}$ & 1.00 & 1.00 & 1.00 & 1.14 & 0.96 \\
\hline \multirow[t]{3}{*}{ Dry deposition } & $\mathrm{Hg}^{0}$ & 1.04 & 1.03 & 0.00 & 1.19 & 1.00 \\
\hline & $\mathrm{Hg}^{\mathrm{II}}$ & 0.44 & 0.67 & 1.02 & 1.16 & 1.00 \\
\hline & $\mathrm{Hg}_{\mathrm{P}}$ & 1.01 & 1.00 & 1.00 & 1.15 & 1.09 \\
\hline \multirow[t]{3}{*}{ Wet deposition } & $\mathrm{Hg}^{0}$ & 1.03 & 1.02 & 1.04 & 1.19 & 1.00 \\
\hline & $\mathrm{Hg}^{\mathrm{II}}$ & 0.44 & 0.67 & 1.02 & 1.18 & 1.00 \\
\hline & $\mathrm{Hg}_{\mathrm{P}}$ & 1.00 & 1.00 & 1.00 & 1.17 & 0.93 \\
\hline
\end{tabular}


raindrop diameters presented in (Duhanyan and Roustan, 2011) and (Duhanyan, 2012) were applied to the in-cloud scavenging model on order to investigated the impact of these parameters on the amount of wet deposition. The implemented scavenging coefficients and representative raindrop diameters together with corresponding results are presented in Tables 5 and 6, respectively.

Presented results in Table 4 shows that the reaction of $\mathrm{Hg}^{0}$ with $\mathrm{BrO}^{\bullet}$ has a crucial impact on the reactive gaseous mercury formation in atmosphere. The removal of $\mathrm{Hg}^{0}$ by dry deposition do not have significant impact of mercury concentration in whole domain. The change of coefficients of in-cloud scavenging leads to increase of mercury wet deposition load of almost 2.5 times. Furthermore, the representative raindrop diameter for in-cloud scavenging has a significant impact on the amount of wet deposited mercury. Comparison of model and observations results presented in Tables 4-6 lead to conclusion that if the reaction of bromine is not implemented to model the scavenging coefficient should be calculated with use of approach lead to highest results of loads of wet deposited mercury. The boundary concentration has a significant impact on amounts (concentration and deposition) of $\mathrm{Hg}^{\mathrm{O}}$ in modelling domain.

\subsection{Results of the simulations over Europe}

The generated yearly average dry deposition velocities from all cells in the European domain for meteorological parameters recorded every $3 \mathrm{~h}$ and for different land types are presented in Fig. 5.

Results of mercury concentration, dry and wet deposition of GEM, RGM and mercury included in particulate matter over Europe in 2008 are presented in Figs. 6-10.

The dry deposition velocity for elemental mercury is around 10 times lower than for reactive mercury (Fig. 5). However, due to the high concentration of GEM $\left(\mathrm{Hg}^{0}\right)$ the dry deposition of $\mathrm{Hg}^{0}$ is higher than the deposition of RGM $\left(\mathrm{Hg}^{\mathrm{II}}\right.$ and $\mathrm{Hg}^{\mathrm{I}}$ ) especially over land (Fig. 10). The detailed analysis showed that the relatively high dry deposition of $\mathrm{Hg}^{0}$ leads to decrease the concretions of this form over land of Europe near $0.2 \mathrm{ng} \mathrm{m}^{-3}$, what causes of significant differences in concentration of $\mathrm{Hg}^{0}$ near boundary and inside domain. In many models (i.e. STEM-Hg) the dry deposition $\mathrm{Hg}^{0}$ is set to 0 because of assumption that this from is immediately remitted to air models (Pan et al., 2010). In our model we provided the remission together with natural emission of mercury (Fig. 4), but this upward flux not balances the dry deposition flux what was also presented in work of (Zhang et al., 2012). The oxidation processes of GEM do not has a significant impact of ambient concentration of this form in air, the chemistry of mercury results the annual maximum decreasing of $\mathrm{Hg}^{0}$ of $60 \mathrm{pg} \cdot \mathrm{m}^{-3}$ in the surface level.

\section{Table 5}

Relative changed of amount of mercury wet deposition in European domain by use of different scavenging coefficients for in-cloud scavenging. The presented values are ratio of the amounts of deposited mercury from model run with the use of listed scavenging coefficients to results of simulation with the use of reference scavenging coefficient proposed by (Maryon et al., 1996). I -intensity of rain $\left[\mathrm{mm} \cdot \mathrm{h}^{-1}\right], \tau_{\text {cld }}$-a cloud timescale (set as $1 \mathrm{~h}$ ), $\frac{1}{\alpha}=\tau_{\text {washout }}=\frac{W_{T} \Delta Z_{\text {cld }}}{I} \cdot 3.6 \cdot 10^{6} \quad[\mathrm{~s}], W_{T}$-the mean total water content [ $\left.\mathrm{m}_{\text {water }}^{3} \cdot \mathrm{m}_{\text {air }}^{-3}\right], \Delta Z_{\text {cld }}$-the cloud vertical thickness [m]. References to parameterisations of scavenging coefficients are presented in (Duhanyan, 2012).

\begin{tabular}{ll}
\hline Scavenging coefficient $\left[\mathrm{s}^{-1}\right]$ & Changed \\
\hline $8.4 \cdot 10^{-5} \cdot \mathrm{I}^{0.79}$ & Reference model \\
$3.5 \cdot 10^{-4} \cdot \mathrm{I}^{0.78}$ & 1.52 \\
$3.36 \cdot 10^{-4} \cdot \mathrm{I}^{0.79}$ & 1.44 \\
$4.17 \cdot 10^{-4} \cdot \mathrm{I}^{0.79}$ & 1.51 \\
$\frac{1-\exp \left(-\alpha \tau_{\text {cld }}\right)}{\tau_{\text {cld }}}$ & 2.30 \\
\hline
\end{tabular}

\section{Table 6}

Relative changed of amount of mercury wet deposition in European domain by use of scavenging coefficients $4.17 \cdot 10^{-7} \cdot \mathrm{I} \cdot 0.9 \cdot \mathrm{D}^{-1}$ proposed in (CAMx, 2005) with the different representative raindrop diameter for in-cloud scavenging model. The presented values are the ratio of the amounts of deposited mercury from model run with the use of listed representative raindrop diameter to results of simulation base on reference scavenging coefficient proposed by (Maryon et al., 1996). References to parameterisations of representative raindrop diameters are presented in (Duhanyan and Roustan, 2011).

\begin{tabular}{ll}
\hline Representative raindrop diameter $\mathrm{D}[\mathrm{m}]$ & Changed \\
\hline $1.238 \cdot 10^{-3} \cdot \mathrm{I}^{0.182}$ & 2.03 \\
$7.88 \cdot 10^{-4} \cdot \mathrm{I}^{0.3}$ & 1.60 \\
$3.97 \cdot 10^{-4} \cdot \mathrm{I}^{0.37}$ & 1.85 \\
$8 \cdot 10^{-4} \cdot \mathrm{I}^{0.34}$ & 1.62 \\
$1.3 \cdot 10^{-3} \cdot \mathrm{I}^{0.14}$ & 1.36 \\
$7 \cdot 10^{-4} \cdot \mathrm{I}^{0.25}$ & 1.61 \\
$1.18 \cdot 10^{-3} \cdot \mathrm{I}^{0.2}$ & 1.42 \\
$1.06 \cdot 10^{-3} \cdot \mathrm{I}^{0.16}$ & 1.44 \\
$1.16 \cdot 10^{-3} \cdot \mathrm{I}^{0.227}$ & 1.44 \\
\hline
\end{tabular}

In 2008, the areas of southern Poland and Greece were areas the most polluted by mercury in Europe. Looking at Fig. 6 can notice that the $\mathrm{Hg}^{0}$ concentrations are evenly distributed (relatively low variations exist). On the contrary, high variations in the spatial gradient of RGM and $\mathrm{Hg}_{\mathrm{P}}$ concentrations observed. The highest concentrations observed near large emission sources. Taking into account these differences in dispersion characteristics, we recommend that the mercury emission databases and inventories for countries should distinguish mercury emissions in different forms. This is important for analysing local mercury impacts for which information on the emissions level of reactive mercury and mercury bounded in particulate matter (including its bin size distribution) is more useful compared to the total mercury emissions.

\subsection{Contribution of different sources to mercury deposition in Poland}

The results of the simulation described in the previous section and the simulation run without anthropogenic sources were used to investigate the contribution of different emission sources i.e. anthropogenic, global, natural and the reemission on mercury deposition in Poland in 2008 (Fig. 11).

The results show the major contribution of natural and global sources and a rather low contribution of European anthropogenic sources. The contribution of national (polish) anthropogenic sources (NPS + NOS) varies in different months from 10 to $22 \%$ and from 6 to 11\% for Polish power sector (NPS). The highest share of national sources is observed during the winter heating season when large quantities of coal is burned in the domestic sector and additionally the power sector activity is at its highest. The contribution of national power sector to all national sources varies from 47 to $66 \%$. The obtained results are in contradiction to results provided by (Ryaboshapko et al., 2007b), where the Polish anthropogenic sources contributed the most to the deposition over Poland in 1999 (range from 45\% according to HYSPLIT model for August to $80 \%$ according to MSCE-HM model in February). In our case the contribution of these sources to deposition is much lower (from $10 \%$ in summer to $22 \%$ in winter). The discrepancies between our results and results presented in (Ryaboshapko et al., 2007b) concerning the contribution of GNR (global, natural and reemission sources) are mainly due to a strong GEM deposition resulting from the use of the resistance scheme proposed by (Zhang et al., 2003). The models presented in (Ryaboshapko et al., 2007b) estimated the dry deposition of mercury of $2-6 \mathrm{~g} \mathrm{~km}^{-2} \cdot \mathrm{y}^{-1}$ over land. Our results show dry deposition of GEM over land of approx. 


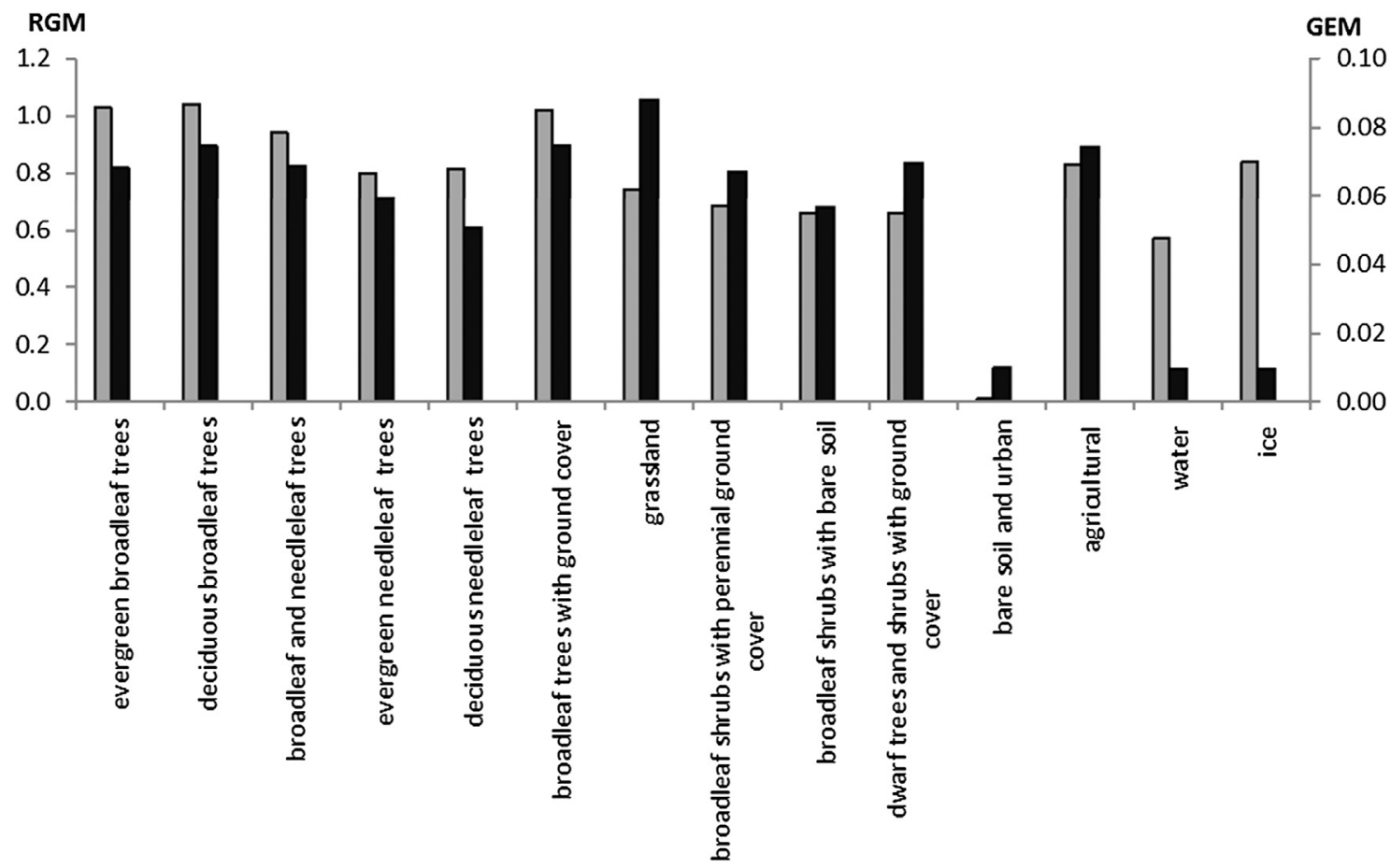

Fig. 5. The average dry deposition velocity of RGM $\left(\mathrm{Hg}^{\mathrm{II}}\right.$ and $\mathrm{Hg}^{\mathrm{I}}$ ) (grey, left axis) and GEM (black, right axis) for different land types over Europe [cm. $\mathrm{s}^{-1}$ ].

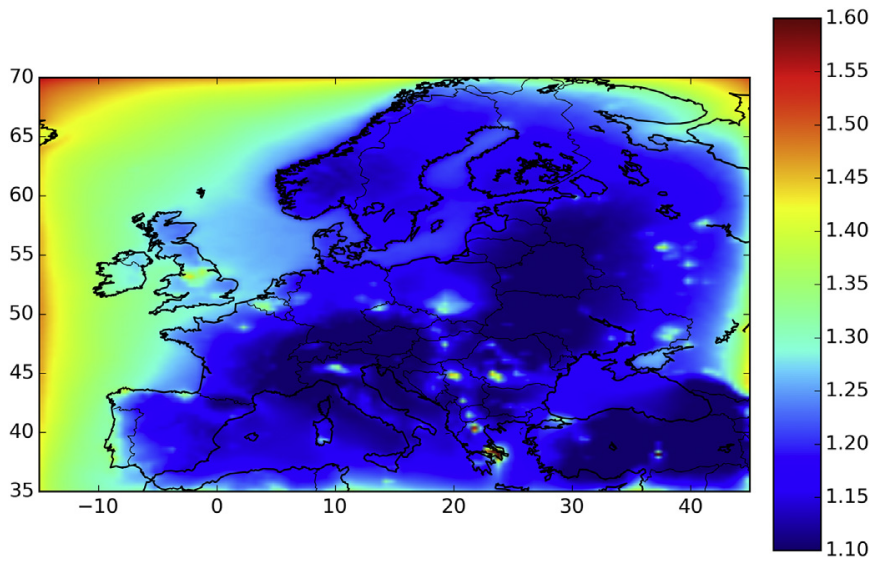

Fig. 6. Annual average concentration of GEM [ng. $\mathrm{m}^{-3}$ ] in the surface level.

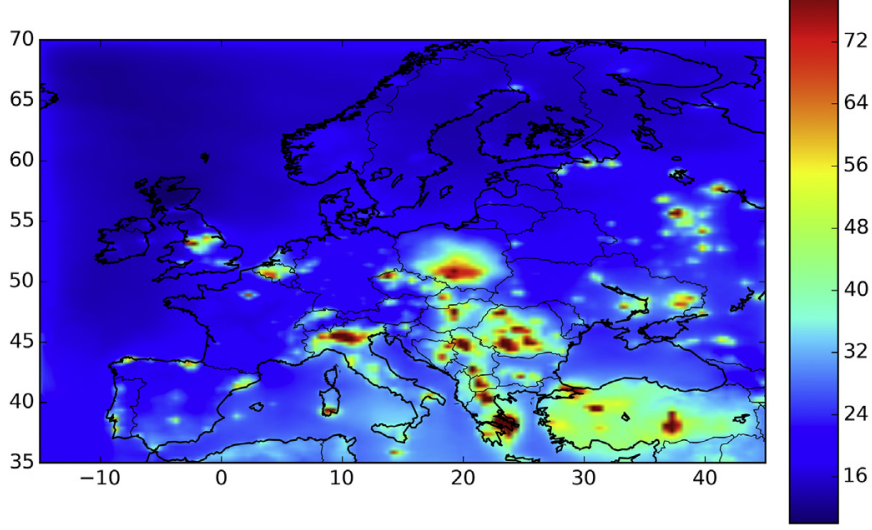

Fig. 7. Annual average concentration of RGM $\left[\mathrm{pg} \cdot \mathrm{m}^{-3}\right]$ in the surface level.

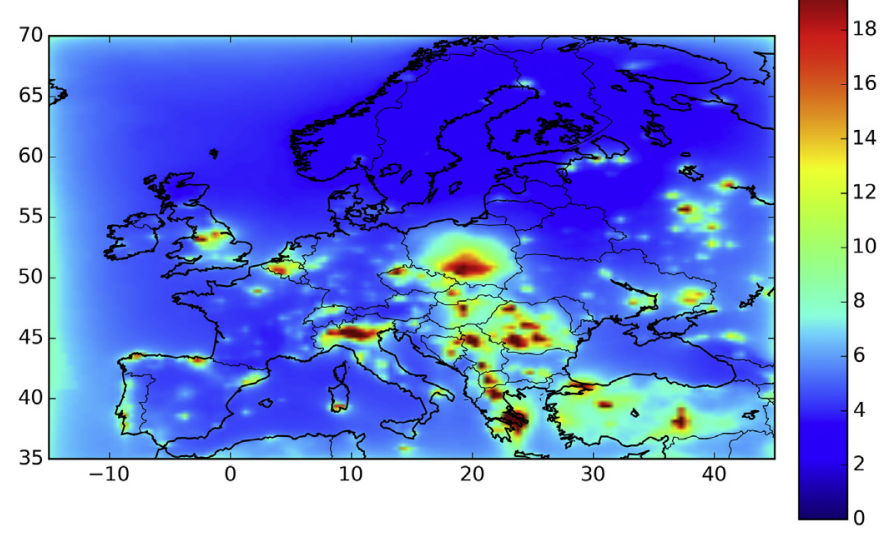

Fig. 8. Annual average concentration of $\mathrm{Hg}_{\mathrm{P}}\left[\mathrm{pg} \cdot \mathrm{m}^{-3}\right]$ in the surface level.

$25 \mathrm{~g} \mathrm{~km}^{-2} \cdot \mathrm{y}^{-1}$. This value of dry deposition load in the view of the recent studies of (Zhang et al., 2012) seems not to be overestimated. The results are similar to those presented in (Ilyin et al., 2010b) for the relative contribution of global, natural and re-emission sources (GNR) and European anthropogenic (EAS) in Europe for 2005.

\subsection{The impact of the Polish power sector}

Detailed simulations with finer resolution and mercury emission data were performed for Poland. The contribution of mercury emissions from the power sector to wet deposition is presented in Fig. 12 and in Fig. 13. To obtain results presented in Fig. 12 the emission data based on (Zyśk et al., 2011) were used. The results in Fig. 13 present the case when emissions for each power plant were calculated based on mercury emission factors from the power sector proposed by (KOBiZE, 2011). It is worth noting that in the wet deposition process only mercury bounded in particulate matter and 


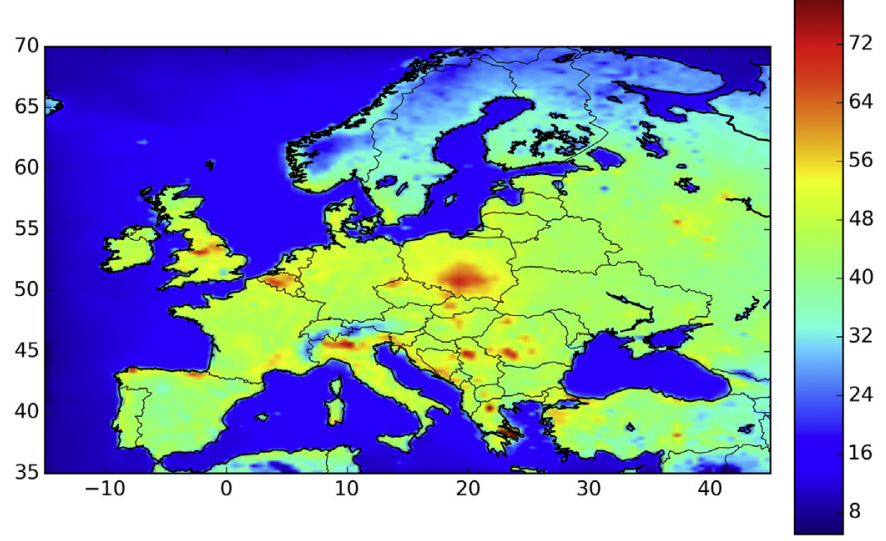

Fig. 9. Annual deposition of mercury $\left[\mathrm{g} \cdot \mathrm{km}^{-2} \cdot \mathrm{y}^{-1}\right]$.

reactive gaseous mercury are removed because $\mathrm{Hg}^{0}$ scavenging is very insignificant. Therefore, the high amount of mercury deposited with precipitation indicates a high concentration of mercury included in particulate matter and reactive gaseous mercury. These forms are deposited locally and can be treated as the indicators of mercury emissions. Due to the differences of mercury emission estimates from the power sector, which were discussed in (Zyśk et al., 2011), the results in Fig. 12 shows a higher contribution of brown coal power plants compared to the results presented in Fig. 13 where contribution is higher over areas where the hard coal power plants are located. Both maps show that in many areas of Poland the power sector is responsible for more than $50 \%$ of total wet deposition. Similar results were obtained for overall dry deposition of reactive mercury $\left(\mathrm{Hg}^{\mathrm{II}}+\mathrm{Hg}^{\mathrm{I}}+\mathrm{Hg}_{\mathrm{P}}\right)$. The contribution of mercury emissions from power sector to the overall dry deposition of GEM equals to max. $10 \%$ and $24 \%$ - in case of the use of emissions proposed by (KOBiZE, 2011) and by (Zyśk et al., 2011), respectively.

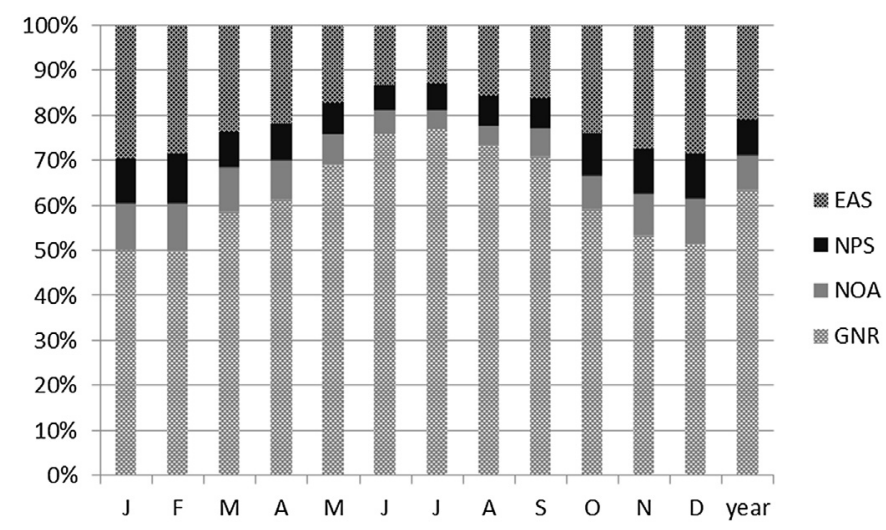

Fig. 11. Contribution of national (polish) power sector (NPS), national other anthropogenic (NOS), European anthropogenic (EAS), and global, natural and re-emission sources (GNR) to total mercury deposition (dry + wet) in each month of 2008 .

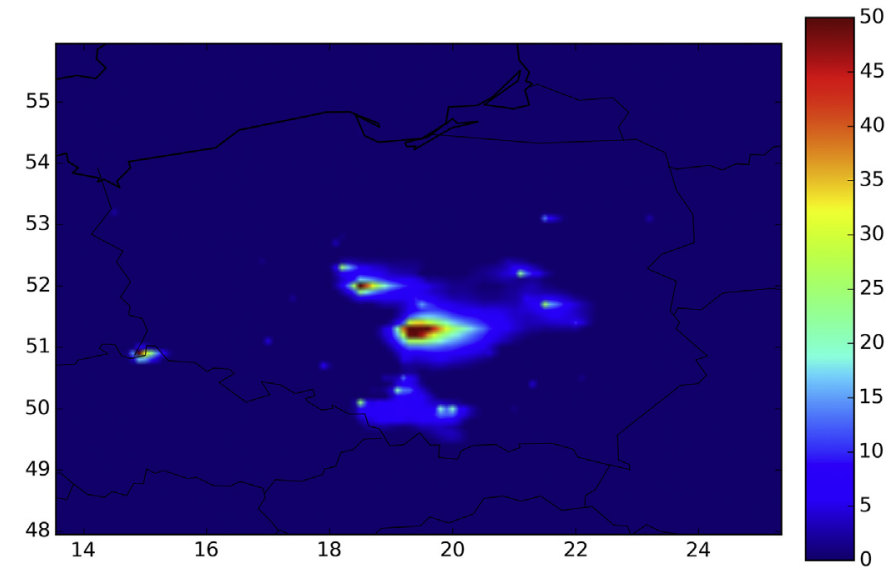

Fig. 12. The impact of the Polish power sector. The percentage rate of emissions from power sector to overall wet deposition [\%]. Emissions of mercury from the power sector following (Zyśk et al., 2011).

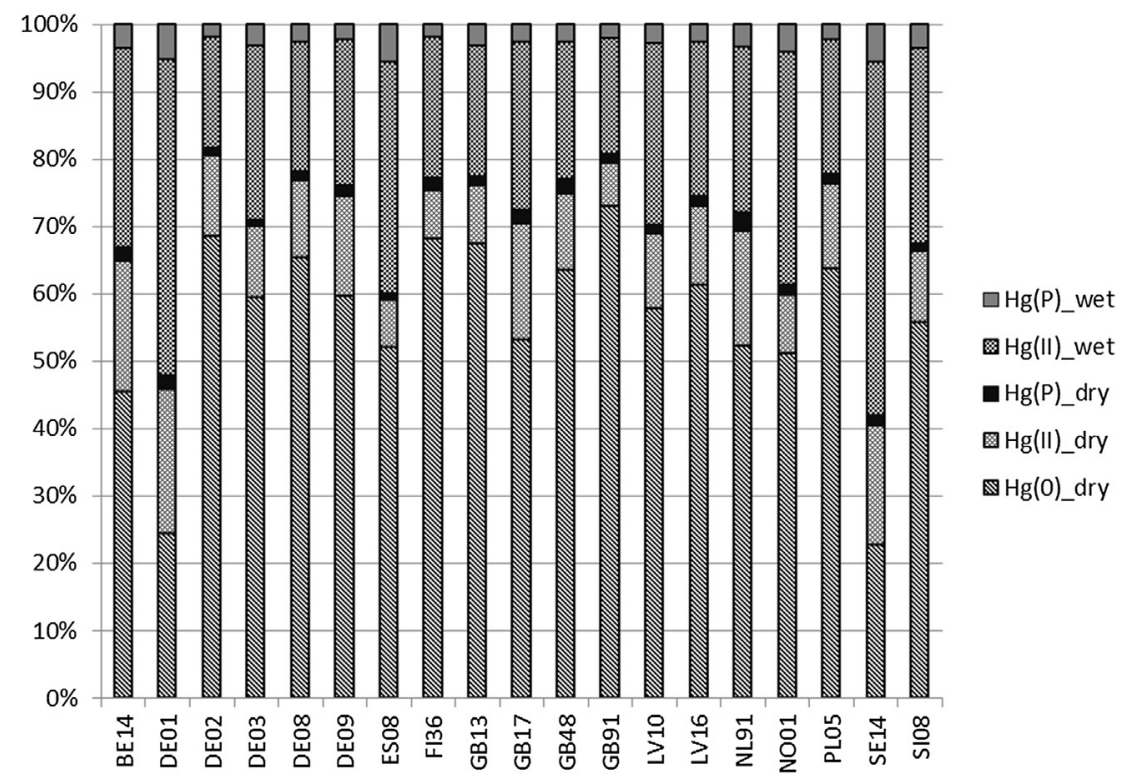

Fig. 10. Contribution of mercury forms to overall deposition (dry and wet) in location of EMEP measurement sites. 


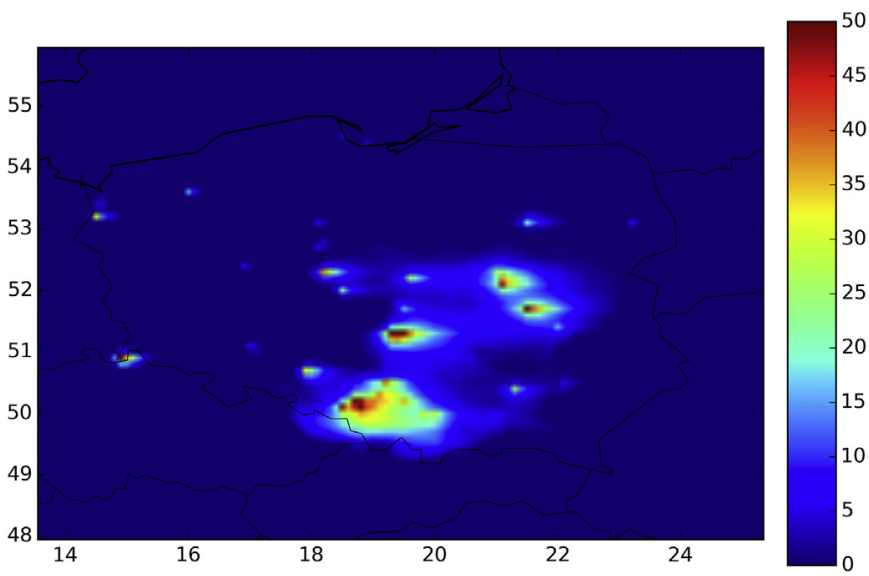

Fig. 13. The impact of the Polish power sector. The percentage rate of emissions from the power sector to overall wet deposition [\%]. Emission from the power sector base on emission factors provided by (KOBiZE, 2011).

\section{Conclusions}

In this paper the applicability of the new chemical model of mercury was demonstrated. The main developments in this model are related to the reactions and transformations of mercury with bromine and the implementation of different sizes of bins for mercury bounded in aerosols. It should be noticed that the reactions with bromine and its compounds has huge impact of mercury chemistry into atmosphere and doubtless increase uncertainties of model, however this improvement is necessary towards complete understanding of mercury atmospheric chemistry. The conducted sensitivity studies shows that many components of developed model have crucial impact of obtained results e.g. the changing of calculation representative raindrop diameter.

This new chemical model implemented into the Polyphemus air quality system made it possible to calculate concentrations and depositions of mercury over Europe in locations where the measurements were not done. In fact, one of the conclusions from this study is that measurements of air concentration and deposition (wet + dry) of mercury should be extended over Europe. The results achieved revealed the areas mostly polluted by mercury. Poland belongs to such areas and the likely reason often indicated is the high mercury emissions from the Polish coal based power sector. In order to analyse the problem of the contribution of mercury emitted from the Polish power sector in more detail, dispersion simulations were done for the smaller domain covering Poland with finer resolution. The performed simulations made it possible for the first time to investigate the contribution of different emission sources i.e. anthropogenic, global, natural and reemission to the mercury total deposition in Poland. The obtained results show that natural and global sources are major contributors and the contribution of European anthropogenic sources is rather low. The contribution from of national sources varies and can be as high as $20 \%$ particularly in the winter season. Moreover the detailed studies over Poland shows that the emission of mercury from big sources of coal power sector locally responds of 50\% of overall mercury reactive dry and wet deposition. These results are very important in the context of preparing a national strategy on mercury reduction as they show to what extend mercury concentration and deposition can be reduced over Poland by means of cutting national emissions. They also show that mercury, to a large extent, is a global pollutant and international agreements and strategies on mercury reductions are necessary to effectively tackle the problem. However the model can be used as a tool supporting decision making to improve the situation in areas with the highest mercury concentrations and depositions. One should keep in mind that the results presented are burdened with uncertainties, which were partly shown and discussed in this paper.

\section{Acknowledgements}

We gratefully acknowledge Mr. Christian Seigneur, Mr. Bruno Sporitsse and Mr. Luc Musson Genon from CEREA Joint Laboratory Ecole des Ponts ParisTech - EDF R\&D and Mr. Janusz Gołaś from AGH University of Science and Technology for their supervision and professional advice.

This work received financial support from the statutory funding of AGH (no. 11.11.210.217).

\section{References}

Aas, W., Breivik, K., 2007. Heavy Metals and POP Measurements, 2011. EMEP/CCCReport 4/2013. Norwegian Institute for Air Research, Kjeller, Norway, p. 136.

Ariya, P.A., Khalizov, A., Gidas, A., 2002. Reactions of gaseous mercury with atomic and molecular Halogens: kinetics, product studies, and atmospheric implications. J. Phys. Chem. A 106, 7310-7320.

Balabanov, N.B., Shepler, B.C., P.K, A, 2005. Accurate global potential energy surface and reaction dynamics for the ground state of $\mathrm{HgBr}_{2}$. J. Phys. Chem. 109, $765-8773$.

Bullock, R., Brehme, K., 2002. Atmospheric mercury simulation using the CMAQ model formulation description and analysis of wet deposition results. Atmos. Environ. 36, 2135-2146.

CAMx, 2005. User's Guide of Comprehensive Air Quality Model, Version 4.20, with Extensions. ENVIRON International Corporation Novato, US, p. 235.

CEIP/EMEP, 2013. The EMEP Centre on Emission Inventories and Projections. http:// www.ceip.at/.

Dean, J.A., 1992. Lange's Handbook of Chemistry. McGraw-hill, Inc., New York.

Donohoue, D.L., Bauer, D., Cossairt, B., Hynes, A., 2006. Temperature and pressure dependent rate coefficients for the reaction of $\mathrm{Hg}$ with $\mathrm{Br}$ and the reaction of $\mathrm{Br}$ with Br: a pulsed laser photolysis - pulsed laser induced fluorescence study. J. Phys. Chem. A 110, 6623-6632.

Duhanyan, N., 2012. Parameterisation of the In-cloud Wet Scavenging of the Atmosphere. CEREA, Ecole des Ponts, ParisTech, Champs-sur-Marne, France.

Duhanyan, N., Roustan, Y., 2011. Below-cloud scavenging by rain of atmospheric gases and particulates. Atmos. Environ. 45, 7201-7217.

ECMWF, Provides Medium-range Weather Forecast Support to European Meteorological Organizations. www.ecmwf.int.

EMEP-CCC, 2013. Chemical Co-ordinating Centre of EMEP (CCC). http://www.nilu. no/projects/ccc/index.html.

Frenzel, A., Scheer, V., Sikorski, R., George, C., Behnke, W., Zetzsch, C., 1998. Heterogeneous interconversion reactions of $\mathrm{BrNO}_{2}, \mathrm{ClNO}_{2}, \mathrm{Br}_{2}$ and $\mathrm{Cl}_{2}$. J. Phys. Chem. A 102, 1329-1337.

Friedrich, R., Reis, S., 2004. Emissions of Air Pollutants - Measurements, Calculation, Uncertainties - Results from the EUROTRAC-2 Subproject GENEMIS. Springer Publishers, Berlin, Heidelberg, Germany.

GLCC/USGS, 2008. Global Land Cover Characteristics. http://edc2.usgs.gov/glcc/glcc. php.

Goodsite, M.E., Plane, J.M.C., Skov, H., 2004. A theoretical study of the oxidation of $\mathrm{Hg} 0$ to $\mathrm{HgBr} 2$ in the troposphere. Environ. Sci. Technol. 38, 1772-1776.

Hall, B., 1995. The gas phase oxidation of elemental mercury by ozone. Water Air Soil Pollut. 80, 301-315.

Hall, B., Bloom, N.S., 1993. Annual Report to the Electric Power Research. EPRI, Palo Alto, US.

Hepler, L.G., Olofsson, G., 1975. Mercury. Thermodynamic properties, chemical equilibriums, and standard potentials. Chem. Rev. 75, 585-602.

Ilyin, I., Gusev, A., Rozovskaya, O., Shatalov, V., Sokovykh, V., Travnikov, O., 2010a. Modelling of Heavy Metals and Persistent Organic Pollutants: New Developments. Technical Report 1/2010 (Draft). EMEP/MSC-E, Moscow.

Ilyin, I., Rozovskaya, O., Shatalov, V., Sokovykh, V., Travnikov, O., Varygina, M., Aas, W., Uggerud, H.T., 2010b. Heavy Metals: Transboundary Pollution of the Environment. EMEP Status Report 2/2010. EMEP/MSC-E EMEP-CCC/NILU, Moscow.

Jacob, D.J., 1986. Chemistry of $\mathrm{OH}$ in remote clouds and its role in the production of formic acid and peroxymonosulfate. J. Geophys. Res. 91D, 9807-9826.

Jonson, J.E.E., Travnikov, O.E., Dastoor, A., Gauss, M., Gusev, A., Hollander, A., Iyin, I., Lin, C.-J., MacLeod, M., Shatalov, V., Sokovykh, V., Valdebenito, A., Valiyaveetil, S., Wind, P., 2010. Development of the EMEP Global Modelling Framework: Progress Report. EMEP/MSC-w Technical Report 1/2010. EMEP/ MSC-E/MSC-W, Moscow/Oslo.

KOBiZE, 2011. National Emission Inventory for $\mathrm{SO}_{2}, \mathrm{NO}_{\mathrm{x}}, \mathrm{NH}_{3}, \mathrm{CO}, \mathrm{PM}, \mathrm{HM}$, VOCs in 2008-2009 in SNAP and NFR Classification (in Polish). National Centre for Emissions Management, Warszawa.

Kosak-Channing, L.F., Helz, G.R., 1983. Solubility of ozone in aqueous solutions of 0-0.6 M ionic strength at 5-300C. Environ. Sci. Technol. 17, 581-591. 
Lecour, E., Seigneur, C., 2013. Dynamic evaluation of a multi-year model simulation of particulate matter concentrations over Europe. Atmos. Chem. Phys. 13, 4319-4337.

Lin, C., Pehkonen, S.O., 1997. Aqueous free radical chemistry of mercury in the presence of iron oxides and ambient aerosol. Atmos. Environ. 31, 4125-4137.

Lin, C., Pehkonen, S.O., 1998a. Oxidation of elemental mercury by aqueous chlorine $\left(\mathrm{HOCl} / \mathrm{OCl}^{-}\right)$: implications for tropospheric mercury chemistry. J. Geophys. Res. 103, 28093-28102.

Lin, C., Pehkonen, S.O., 1998b. Two-phase model of mercury chemistry in the atmosphere. Atmos. Environ. 32, 2543-2558.

Lindqvist, O., Rodhe, H., 1985. Atmospheric mercury - a review. Tellus.

Louis, J.F., 1979. A parametric model of vertical eddy fluxes in the atmosphere. Bound.-Layer Meteorol. 17, 187-202.

Mallet, V., Quello, D., Sportisse, B., Ahmed de Biasi, M., Debry, E., Korsakissok, I., Wu, L., Roustan, Y., Sartelet, K., Tombette, M., Foudhil, H., 2007. Technical Note: The air quality modeling system Polyphemus, 7, pp. 5479-5487.

Maryon, R.H., Saltbones, J., Ryall, D.B., Bartnicki, J., Jakobsen, H.A., Berge, E., 1996. An Intercomparison of Three Long Range Dispersion Models Developed for the UK Meteorological Office, DNMI and EMEP., UK Met Office Turbulence and Diffusion Note 234. UK Meteorological Office (Bracknell, United Kingdom).

Munthe, J., 1992. The aqueous oxidation of elemental mercury by ozone. Atmos. Environ. 26A, 1461-1468.

Munthe, J., Bodaly, R.A., Branfireun, B.A., Driscoll, C.T., Gilmour, Cynthia C., Harris, Reed, Horvat, M., Lucotte, M., Malm, O., 2007. Recovery of mercurycontaminated fisheries. Ambio 36, 33-44.

Nazhat, N.B., Asmus, K.D., 1973. Reduction of mercuric chloride by hydrated electrons and reducing radicals in aqueous solutions. Formation and reactions of mercury chloride ( $\mathrm{HgCl})$. J. Phys. Chem. 77, 614-620.

Pacyna, E., Pacyna, J., Fudala, J., Strzelecka-Jastrząb, E., Hławiczka, S., Panasiuk, D., 2006. Mercury emissions to the atmosphere from anthropogenic sources in Europe in 2000 and their scenarios until 2020. Sci. Total Environ. 370, 147-156.

Pan, L., Lin, C.-J., Carmichael, G.R., Streets, D.G., Youhua Tang, Y., Jung-Hun Woo, J.H., S.K, S., Chu, H.W., Ho, T.C., Friedli, H.R., Feng, X., 2010. Study of atmospheric mercury budget in East Asia using STEM-Hg modeling system. Sci. Total Environ. 408, 3277-3291.

Pehkonen, S.O., Lin, C., 1998. Aqueous photochemistry of mercury with organic acids. J. Air Waste Manag. Assoc. 48 (2), 144-150.

Petersen, G., Munthe, J., Iverfeldt, A., 1995. Atmospheric mercury species over Central and Northern Europe. Model calculations and comparison with observations from the nordic air and precipitation network for 1987 and 1988 . Atmos. Environ. 29, 47-67.

Poulain, A.J., Garcia, E., Amyot, M., Campbell, P.G.C., c, P.A.A., 2007. Mercury distribution, partitioning and speciation in coastal vs. inland high Arctic snow. Geochim. Cosmochim. Acta 71, 3419-3431.

Raofie, F., Ariya, P.A., 2003. Reactions of BrO with mercury: kinetic studies. J. Phys. IV Fr. 107, 1119-1121.

Roustan, Y., Bocquet, M., 2006. Inverse modelling for mercury over Europe. Atmos. Chem. Phys. 6, 3085-3098.

Roustan, Y., Bocquet, M., Musson Genon, L., Sportisse, B., 2005. Modeling atmospheric mercury at European scale with the chemistry transport model Polair 3D. In: Brandt, K., Frohn, L.M. (Eds.), 2nd GLOREAM/EURASAP Workshop. National Environmental Research Institute (Denamark), Copenhagen.

Ryaboshapko, A., Artz, R., Bullock, R., Christensen, J., Cohen, M., Dastoor, A., Davignon, D., Draxler, R., Ilyin, I., Munthe, J., Pacyna, J., Petersen, G., Syrakov, D., Travnikov, O., 2003. Intercomparison study of numerical models for long-range atmospheric transport of mercury. Stage II : Comparison of modeling results with observations obtained during short-term measuring campaigns. EMEP/ MSC-E.

Ryaboshapko, A., Bulloc, R., Christensen, J., Cohen, M., Dastoor, A., Ilyin, I., Petersen, G., Syrakov, D., Artz, R., Davignon, D., Draxler, R., Munthe, J., 2007a. Intercomparison study of atmospheric mercury models, 1. Comparison of models with short-term measurements. Sci. Total Environ. 376, 228-240.

Ryaboshapko, A., Bullock, R., Christensen, J., Cohen, M., Dastoor, A., Ilyin, I., Petersen, G., Syrakov, D., Travnikov, O., Artz, R.S., Davignon, D., Draxler, R.R., Munthe, J., Pacyna, E.J., 2007b. Intercomparison study of atmospheric mercury models: 2. Modelling results vs. long-term observations and comparison of country deposition budgets. Sci. Total Environ. 377, 319-333.

Sanemasa, I., 1975. The solubility of elemental mercury vapor in water. Bull. Chem. Soc. Jpn. 48, 1795-1798.
Schroeder, W.H., Munthe, J., 1998. Atmospheric mercury - an overview. Atmos Environ. 32, 809-822.

Schwartz, S.E., 1984. Gas- and aqueous-phase chemistry of HO2 in liquid water clouds. J. Geophys. Res. 89, 11589-11598.

Seigneur, C., Abeck, H., Chia, G., Reinhard, M., Bloom, N.S., Prestbo, E., Pradeep, S. 1998. Mercury adsorption to elemental carbon (soot) particles and atmospheric particulate matter. Atmos. Environ. 32, 2649-2657.

Seigneur, C., Vijayaraghavan, K., Lohman, K., Levin, L., 2009. The AER/EPRI globa chemical transport model for mercury (CTM-HG). In: Pirrone, N., Mason, R. (Eds.), Mercury Fate and Transport in the Global Atmosphere. Springer, London, New York, pp. 589-602.

Seinfeld, J., 1985. Atmospheric Physics and Chemistry of Air Pollution. Wiley.

Sillen, G.L., Martell, A.E., 1964. Stability Constants of Metal Ion Complexes. Special Publication of the Chemical Society, London, p. 17.

Smith, R.M., Martell, A.E., 1976. Critical Stability Constants. In: Inorganic Complexes, vol. 4. Plenum, New York.

Sommar, J., Gardfeldt, K., Stromberg, D., Feng, X., 2001. A kinetic study of the gasphase reaction between the hydroxyl radical and atomic mercury. Atmos. Environ. 35, 3049-3054.

Spicer, C.W., Chapman, E.G., Finlayson-Pitts, B.J., Plastridge, R.A., Hubbe, J.M. Fast, J.D., Berkowitz, C.M., 1998. Unexpectedly high concentrations of molecular chlorine in coastal air. Nature 394, 353-356.

Sportisse, B. du Bois, L., 2002. Numerical and theoretical investigation of a simplified model for the parameterization of below-cloud scavenging by falling raindrops. Atmos. Environ. 36, 5719-5727.

Subir, M., Ariya, P.A., Dastoor, A.P., 2011. A review of uncertainties in atmospheric modeling of mercury chemistry I. Uncertainties in existing kinetic parameters Fundamental limitations and the importance of heterogeneous chemistry. Atmos. Environ. 45.

Travnikov, O., Ryaboshapko, A., 2002. Modeling of Mercury Hemispheric Transport and Depositions, EMEP Raport 6/2002. EMEP/MSC-E, Moscow.

Troen, I.B., Mahrt, L., 1986. A simple model of the atmospheric boundary layer; sensitivity to surface evaporation. Bound.-Layer Meteorol. 37, 129-148.

UNEP, 2014. Minamata Convention on Mercury. http://www.mercuryconvention. org/.

Uplinger, W.G., 1981. A New Formula for Raindrop Terminal velocity., 20th Conference on Radar Meteorology. American Meteorological Society, Boston, Massachusetts, US

Van Loon, L., Mader, E., Scott, S.L., 2000. Reduction of the aqueous mercuric ion by sulfite: UV spectrum of $\mathrm{HgSO}_{3}$ and its intramolecular redox reaction. J. Phys. Chem. 104, 1621-1626.

Van Loon, L.L., Mader, E.A., Scott, S.L., 2001. Sulfite stabilization and reduction of the aqueous mercuric ion: kinetic determination of sequential formation constants. J. Phys. Chem. 105, 3190-3195.

Wang, Z., Pehkonen, S.O., 2004. Oxidation of elemental mercury by aqueous bromine: atmospheric implications. Atmos. Environ. 38, 3675-3688.

Willis, P.T., 1984. Functional Fits to Some Observed Drop Size Distributions and Parameterization of Rain. J. Atmos. Sci. 41, 1648-1661.

Xie, Z.Q., Sander, R., Poschl, U., Slemr, F., 2008. Simulation of atmospheric mercury depletion events (AMDEs) during polar springtime using the MECCA box model. Atmos. Chem. Phys. 8, 7165-7180.

Yang, X., Cox, R.A., Warwick, N.J., Pyle, J.A., Carver, G.D., O'Connor, F.M., Savage, B.H., 2005. Tropospheric bromine chemistry and its impacts on ozone: A model study. J. Geophys. Res. 110, D23311.

Zhang, L., Brook, J.R., Vet, R., 2003. A revised parameterization for gaseous dry deposition in air-quality models. Atmos. Chem. Phys. 3, 2067-2082.

Zhang, L., Gong, S., Padro, J., Berrie, L., 2001. A size-segregated particle dry deposition scheme for an atmospheric aerosol module. Atmos. Environ. 35, 549-560.

Zhang, L.P., Blanchard, P., Johnson, D., Dastoor, A., Ryzhkov, A., Lin, C.J. Vijayaraghavan, K., Gay, D., Holsen, T.M., Huang, J., Graydon, J.A., St Louis, V.L. Castro, M.S., Miller, E.K., Marsik, F., Luk, J., Poissant, L., Pilote, M., Zhang, K.M., 2012. Assessment of modeled mercury dry deposition over the Great Lakes region. Environ. Pollut. 161, 272-283.

Zhang, L., Wright, L.P., Blanchard, P., 2009. A review of current knowledge concerning dry deposition of atmospheric mercury. Atmos. Environ. 43, 5853-5864.

Zyśk, J., Wyrwa, A., Pluta, M., 2011. Emissions of mercury from the power sector in Poland. Atmos. Environ. 45, 605-610. 